\title{
Trade Liberalization in Latin America and Eastern Europe: the Cases of Ecuador and Slovenia
}

\author{
Sang-Wook (Stanley) Cho \\ University of New South Wales
}

\author{
Julián P. Díaz \\ Bowdoin College
}

\begin{abstract}
We analyze the potential effects of ongoing trade reforms: Ecuador signing an FTA with the US, and Slovenia joining the EU. We construct a static Applied General Equilibrium Model and perform numerical experiments eliminating all import tariffs. Based on Input-Output tables, we construct Social Accounting Matrices for each country for calibration. Additional experiments are performed: sensitivity analyses on the trade elasticities, partial liberalizations, fiscal impacts of eliminating tariff revenues, and an alternative Slovenian liberalization framework. We find that both countries benefit from these reforms, with import prices falling and exports rising. However, different arrangements of trade liberalization have different implications on trade and welfare patterns.
\end{abstract}

- JEL Classification: F14, F15

- Key Words: trade liberalization, free trade agreement, customs union, fiscal policy, Ecuador, Slovenia

\footnotetext{
*Corresponding address: Sang-Wook (Stanley) Cho: School of Economics: Australian School of Business, University of New South Wales, Sydney, 2052, NSW, Australia, Tel: +61 (2) 93853287 Fax: +61 (2) 93136337 e-mail: s.cho@unsw.edu.au.

Julian P. Diaz, Department of Economics, Bowdoin College, 9700 College Station, Brunswick, Maine, 04011, USA, Tel: +1 (207) 7984333 Fax: + 1 (207) 725 3691, e-mail: jdiaz@bowdoin.edu. 


\section{Introduction}

In the recent years, a wave of trade liberalization episodes has swept the globe. In May 2004, ten countries in Central and Eastern Europe (Cyprus, the Czech Republic, Estonia, Hungary, Latvia, Lithuania, Malta, Poland, Slovakia, and Slovenia) joined the European Union as full members. In Latin America, several countries in the region have signed or are currently under negotiations for a bilateral Free Trade Agreement (FTA) with the United States. The Chile-United States Free Trade Agreement entered into effect in January 2004. Negotiations of the DR-CAFTA (the set of bilateral Free Trade Agreements between the Dominican Republic (DR), Costa Rica, El Salvador, Guatemala, Honduras, Nicaragua, and the United States) ended in 2005 and have been ratified by all countries involved by October 2007. Colombia, Ecuador and Peru are currently negotiating similar FTAs with the United States. Other countries are expected to start negotiations in the near future.

These trade liberalization reforms propose, among other things, the elimination of all tariffs and non-tariff barriers among the signing parties. For example, the North American Free Trade Agreement (which has been used as a template for the FTAs under negotiation in Latin America), mandated the complete elimination of tariffs on trade among the United States, Mexico and Canada over a period of 15 years, and a substantial elimination of the non-tariff barriers over the same period. Consequently, these trade liberalization reforms can have a potentially large impact on the economies of the signing countries, especially if the trade relationship is important for at least one of the parties.

This paper concentrates on the effects of two of these ongoing trade liberalization episodes: Ecuador signing a FTA with the United States, and Slovenia joining the European Union. Although these are two small economies, the impact of these reforms is potentially large, because both the United States and the European Union are the main trade partners of Ecuador and Slovenia, respectively.

Many questions arise: What are the effects on the production structure of the economy? What sectors' output will expand or contract? Will exports or imports of a particular sector increase or decrease? What are the magnitudes of these changes? What will happen to the prices that domestic consumers face? What will happen to the welfare of the consumers as trade is liberalized? What are the similarities and differences of the different types of trade reforms by the two countries? This paper aims to provide a quantitative answer to most of these questions. 
To conduct our analysis, a standard static applied general equilibrium model is used, following the tradition of Shoven and Whalley (1984). Applied general equilibrium models have been the tool of choice to analyze the effects of these particular trade liberalization reforms. Examples of applied general equilibrium models used to quantify the effect of trade liberalization policies can be found, for instance, in Kehoe (1996) or Kehoe (2004).

Using Input-Output tables, we construct Social Accounting Matrices (SAM) for Ecuador and Slovenia, and these matrices are then used to calibrate most of the parameters of the artificial economies that are modelled. Once the model has been completely specified and the parameters have been calibrated, two simple comparative statics experiments are performed (labelled as the "benchmark" numerical experiments). For the case of Ecuador, the tariffs that Ecuador imposes on United States imports and the tariffs that the United States imposes on Ecuadorian imports are eliminated (all other tariff rates on other trade partners' imports are kept unchanged) and the effects on sectoral production, exports, imports, prices and welfare are highlighted. For Slovenia, we assume that Slovenia and the European Union eliminate the import tariffs that they impose on one another, and that Slovenia, as a new member of the European Union, adopts the European Union's tariff schedule for imports from the rest of the world. Similarly, the effects on sectoral output, exports, imports, prices and welfare are traced out.

Note that the experiments conducted on Ecuador and Slovenia are different: because Ecuador is only signing a bilateral FTA with the United States, Ecuador does not necessarily have to change its tariff schedule for imports with the rest of the world. On the other hand, Slovenia, as a new member of the European Union, must adopt the tariff schedule that the EU, as a customs union (although membership of the EU implies much more than a customs union), imposes on imports from the rest of the world. In light of the differences in the economic conditions of the two countries, the similarities and differences from the trade reforms are highlighted.

We find that for Ecuador, domestic production increases in the export sectors while prices fall in the main import sectors. Exports of primary and manufactured goods to the United States increase by $35 \%$ as a result of trade creation, while imports from the United States also increase by $46 \%$. Despite improvement in the consumer welfare $(0.90 \%)$, the overall social welfare increases by $0.21 \%$, due to large tariff revenue loss and subsequent decline in government welfare $(-4.36 \%)$. For Slovenia, the effects on prices and domestic production are similar to those of 
Ecuador, but since most sectors are engaged in both export and import activities, the patterns are not as clear as those of Ecuador. Prices fall in the food and beverages, textiles, leather, and transport sectors, whereas domestic production increases in the primary, textiles, transport and other manufacturing sectors. While the effects of trade creation are also large for Slovenia, with exports to and imports from the European Union increasing by $47 \%$ and $32 \%$, respectively, some sectors suffer from diversion of trade with the adoption of European Union's tariff policy. On the other hand, with a more protectionist tariff schedule, the government tariff revenue increases by $4 \%$. Coupled with increases in both the consumer $(1.37 \%)$ and the government welfare $(2.85 \%)$, the social welfare also increases by $1.66 \%$. Contrary to the Ecuadorian case, the consumer gains are larger and the Slovenian government actually gains from joining the European Union.

To complement our analysis, we perform several additional numerical experiments. For example, since most trade liberalization agreements follow a gradual transition period rather than an instantaneous tariff removal, we conduct a numerical experiment to assess the implications of a "partial" liberalization where the tariff rates are not completely removed but instead lowered to a uniform rate. The qualitative implications from the partial liberalization are similar to the benchmark case, but quantitatively, the magnitude is smaller as a partial liberalization can be interpreted as an intermediate step towards full liberalization. As for welfare analysis, the social welfare improves by $0.10 \%$ for Ecuador and $1.38 \%$ for Slovenia, respectively.

In addition, in the benchmark numerical experiment all the elasticities of substitution (for both imports and exports) were assumed to be the same across sectors. We perform a sensitivity analysis with differentiated values for the import elasticities of substitution for each sector, and explore the implications on prices, production, trade, and welfare. We take two sets of values from the literature, one from Hummels (2001) and the other from Rolleigh (2003). The quantitative implications are further amplified for sectors with higher elasticities of substitution. For example, Rolleigh (2003) reports import elasticities of substitution parameter $\rho_{m}$ to be 0.91 in the transportation equipments sector. Compared to the benchmark case where $\rho_{m}=0.8$ for all sectors, the domestic production in the transport sector falls by more than $15 \%$ in Ecuador, which is more than three times the magnitude shown under the benchmark case $(-4 \%)$. As for external trade, exports to the United States for Ecuador increase by $38 \%$ to 59\%, while imports from the United States increase by $52 \%$ to $84 \%$. For Slovenia, exports to the European Union 
increase by $33 \%$ to $49 \%$, whereas the imports from the European Union increase by $48 \%$ to $64 \%$. Especially, in the food and beverages sector, where Rolleigh (2003) reports import elasticities of substitution parameter $\rho_{m}$ of 0.95 , changes in the imports from the European Union and from the rest of the works are four times larger in magnitude than those under the benchmark case.

Furthermore, some country-specific numerical experiments relevant for policymakers are performed: first, in developing economies like Ecuador, tariff revenues not only are used to protect certain productive sectors, but also represent an important source of revenues for the central government. Between 1990 and 2004, tariff revenues in Ecuador have accounted, on average, for around $10 \%$ of the total revenues of the central government. Recall that the United States is the main trade partner of Ecuador. Thus, by signing the Free Trade Agreement and eliminating all tariff rates on imports from the United States, the Ecuadorian government is sacrificing an important stream of revenues. Our numerical experiment consists of finding what increase in other taxes (specifically, the Value Added Tax) must be imposed to compensate the loss of revenues generated by giving up the tariffs on US imports. We find that the required increase in the effective VAT rate ranges from $0.5 \%$ to $1.0 \%$. However, raising the taxes puts burden on the consumer side and lowers the magnitude of consumers' welfare. Compared to the benchmark case ( $0.90 \%)$, the consumer welfare rises by $0.2 \%$ to $0.4 \%$.

A second country-specific numerical experiment is performed for Slovenia. We discover that, by joining the European Union, Slovenia must adopt a tariff schedule that is more protectionist than the one it previously had. This is especially important for the case of primary goods, which Slovenia mainly imports from countries outside the European Union. The numerical experiment that we perform allows Slovenia to mutually eliminate its tariff barriers with the European Union while retaining its tariff schedule with the rest of the world. Under this "free trade agreement" experiment, both the exports and imports with the rest of the world increase, contrary to the benchmark case where the trade with the rest of the world decreases significantly. As for welfare impact, consumer welfare gain is approximately $28 \%$ larger while the government welfare gain is around $70 \%$ smaller than those under the benchmark case. The overall social welfare gain is around $1.58 \%$, slightly less than the gain shown under the benchmark case.

Our final experiment involves a sensitivity analysis on the parameter governing the export elasticity of substitution, $\rho_{x}$. We test for different values of $\rho_{x}$ ranging from 0.8 to 0.95 , and check the robustness of our results on the welfare analysis for 
Ecuador and Slovenia. For Ecuador, we compare the different results of trade liberalization scenarios and confirm that the full liberalization case of free trade agreement always results in higher social welfare than the case of partial liberalization, regardless of the value of $\rho_{x}$. For Slovenia, however, this is not always the case. For values of $\rho_{x}$ lower than 0.93 , the social welfare increase is higher under the customs union than under the free trade agreement scenario. However, for values of $\rho_{x}$ higher than 0.93 , the welfare increase becomes larger under the free trade agreement scenario. All these results are in line with the implications of optimal tariff discussed by Johnson (1954).

The remainder of this paper is organized as follows: Section II provides a brief overview of the external sectors of both Ecuador and Slovenia, discusses the sectoral disaggregation that is used, and details the sources and features of the data that is used. Section III presents the model used, and Section IV describes the calibration results; Section $\mathrm{V}$ discusses the results of the benchmark numerical experiment, as well as the results of the additional numerical experiments mentioned above; Section VI presents some concluding remarks, and lays out some possible extensions for future research.

\section{Background and Data}

\section{A. A Brief Overview}

This section provides a brief overview of the main features of the foreign sectors of Ecuador and Slovenia. This overview is not intended to be a comprehensive description of the external sectors of these two countries, but rather a quick summary of their most important features. A more detailed exposition can be found in the Trade Policy Reviews that the World Trade Organization publishes. The most recent Trade Policy Review for Ecuador is the June 2005 issue and for Slovenia is the May 2002 issue.

\section{(1) Ecuador}

Ecuador is a relatively open economy. From 1990 to 2004, the "openness" ratio (the sum of exports plus imports as a percentage of GDP) was around $60 \%$, on average. Ecuador's main trade partner is the United States. According to Figure 1 in the Appendix, in 2004 the US accounted for $42.85 \%$ of Ecuador's merchandise exports and $16.52 \%$ of its imports. Another important trade partner is the Andean Community (a regional trade bloc composed of Bolivia, Colombia, Ecuador, Peru, 
Figure 1. Ecuador - Geographical Distribution of Merchandise Trade

Destination of Merchandise Exports (2004)

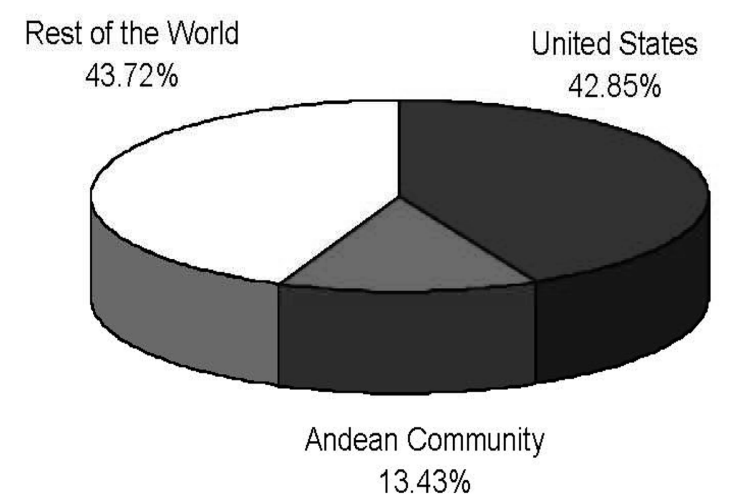

Origin of Merchandise Imports (2004)

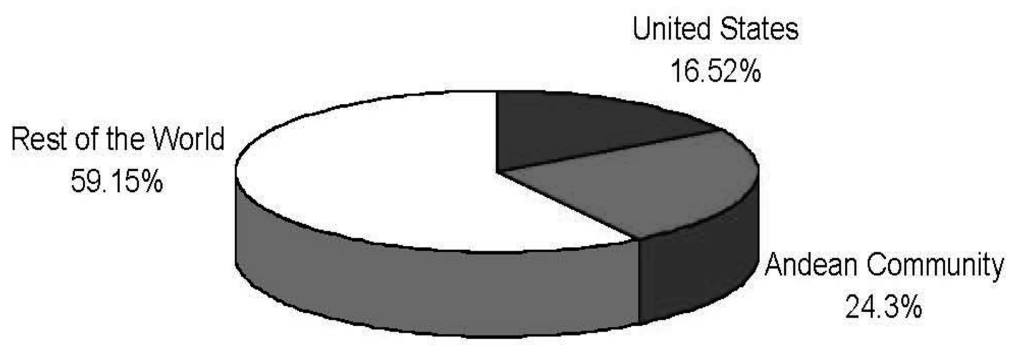

Source: International Monetary Fund, Direction of Trade Statisics(2005)

and Venezuela), which accounted, in 2004, for roughly $13.43 \%$ of Ecuador's exports and $24.3 \%$ of its imports. The European Union, Japan, Korea and, more recently, China are among other important trade partners.

In terms of trade composition, Ecuador is basically an exporter of primary goods. Its main export goods are crude petroleum, bananas, flowers, and shrimp. On the other hand, it mainly imports chemical products, machinery and transportation equipments, and capital goods. Figure 2 contains more detailed information regarding the composition of imports and exports for Ecuador.

Finally, it is important to note that Ecuador has a relatively low tariff rate schedule. The weighted average tariff rate implied by the data is $5.89 \%$ (the simple average of the tariff rate code is around $11 \%$ ). However, there are certain sectors that are heavily protected, such as cereals, shrimp, textiles, and transportation equipment, with implied tariff rates of $13.20 \%, 20 \%, 9.88 \%$ and $12.93 \%$, 
Figure 2. Ecuador - Composition of Exports and Imports

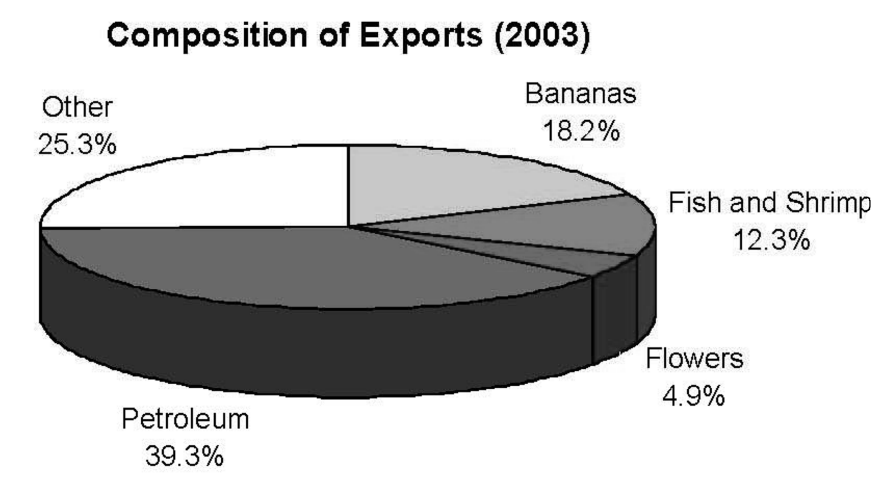

Composition of Imports (2003)

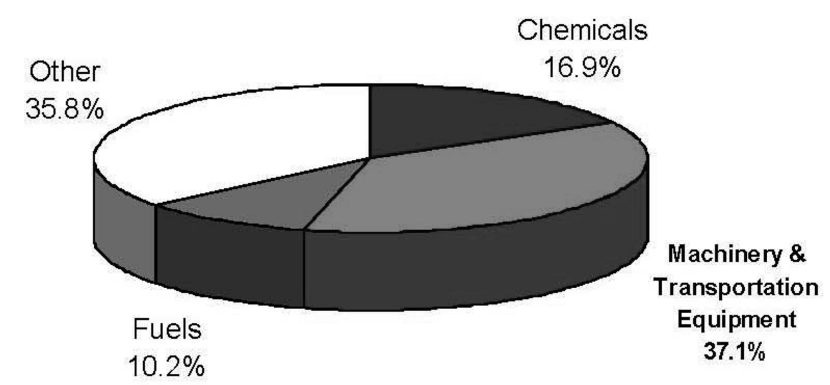

Source: World Trade Organization, Trade Policy Review Ecuador (2005)

respectively.

\section{(2) Slovenia}

Since its independence in 1991, Slovenia has become a very open economy. From 1991 to 2003, the "openness" ratio has averaged 118\%. The European Union is by far its most important trade partner, accounting, in 2004, for roughly $60 \%$ of Slovenia's exports and more than $80 \%$ of its imports. Other trade partners include Croatia, the United States and Bosnia and Herzegovina, but their individual importance is very small when compared to the European Union. Figure 3 contains a more detailed breakdown of the relative weights of Slovenia's trade partners.

In terms of foreign trade composition, primary goods represent a small fraction of Slovenia's imports and exports (accounting for 6\% and 17\% in 2000, respectively), but the majority of the foreign trade of primary goods is conducted with non-members of the European Union. Around 55\% of both exports and imports of primary goods in 2001 was with non-EU members. In contrast, trade in 
Figure 3. Slovenia - Geographical Distribution of Merchandise Trade

\section{Destination of Merchandise Exports (2004)}

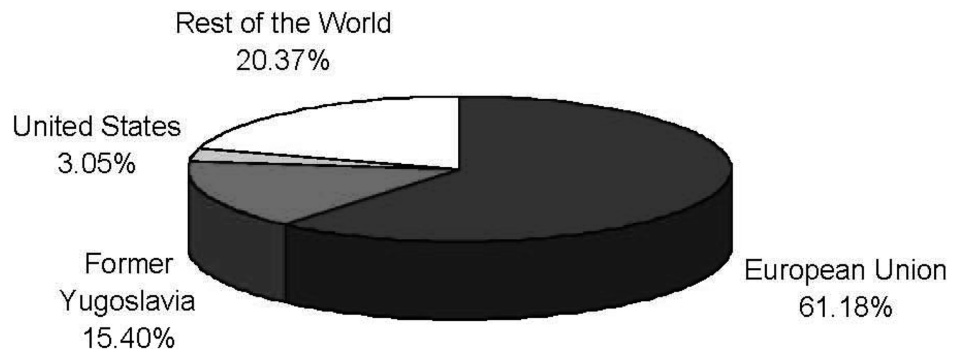

Origin of Merchandise Imports (2004)

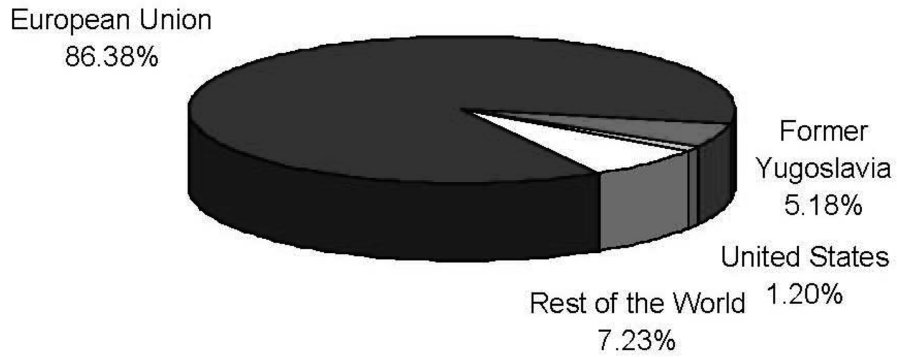

Source: International Monetary Fund, Direction of Trade Statistics (2005)

manufactured goods is strongly biased towards members of the European Union. Around $62 \%$ of total exports of manufactures and $70 \%$ of total imports of manufactures were with EU countries. More detailed information can be found in Figures 4 and 5.

Slovenia has a relatively low tariff schedule, especially when compared to the European Union's tariff schedule. Figure 6 shows the tariff rates for the sectors used in Slovenia's analysis. In general, Slovenia's tariff rates are lower than those of the European Union, and this difference is more evident in the primary goods and food and beverage sectors. This might have a potentially large effect in terms of how Slovenia's imports will evolve in the future. By adopting a more protectionist tariff schedule, Slovenian imports of primary goods will likely switch from nonEU members to EU members.

\section{B. Sectoral Disaggregation}

As mentioned earlier, the main objective of this paper is to quantify the impact 
Figure 4.Slovenia - Composition of Exports and Imports.

\section{Composition of Exports (2000)}

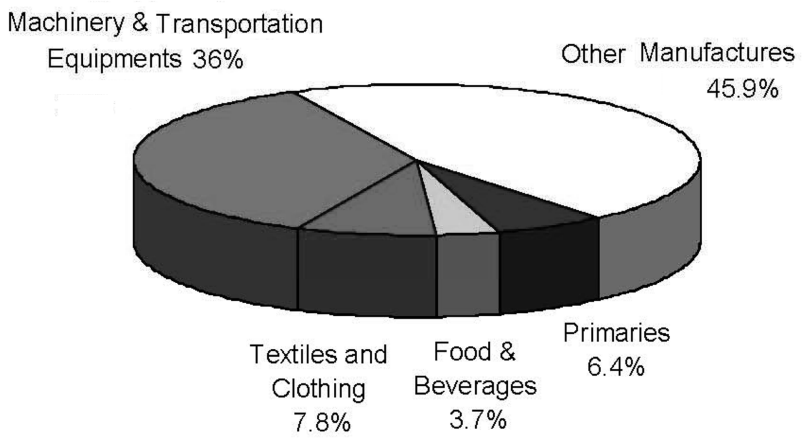

Composition of Imports (2000)

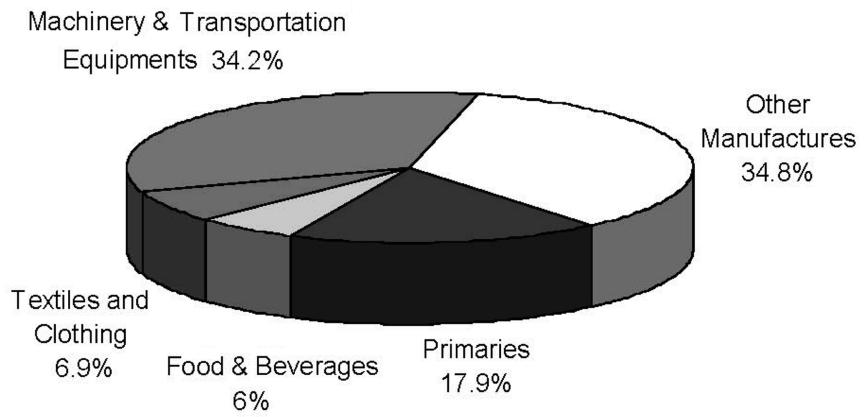

Source: World Trade Organization, Trade Policy Review Slovenia (2002)

Figure 5. Slovenia - Trade in Primary and Manufactured Goods.

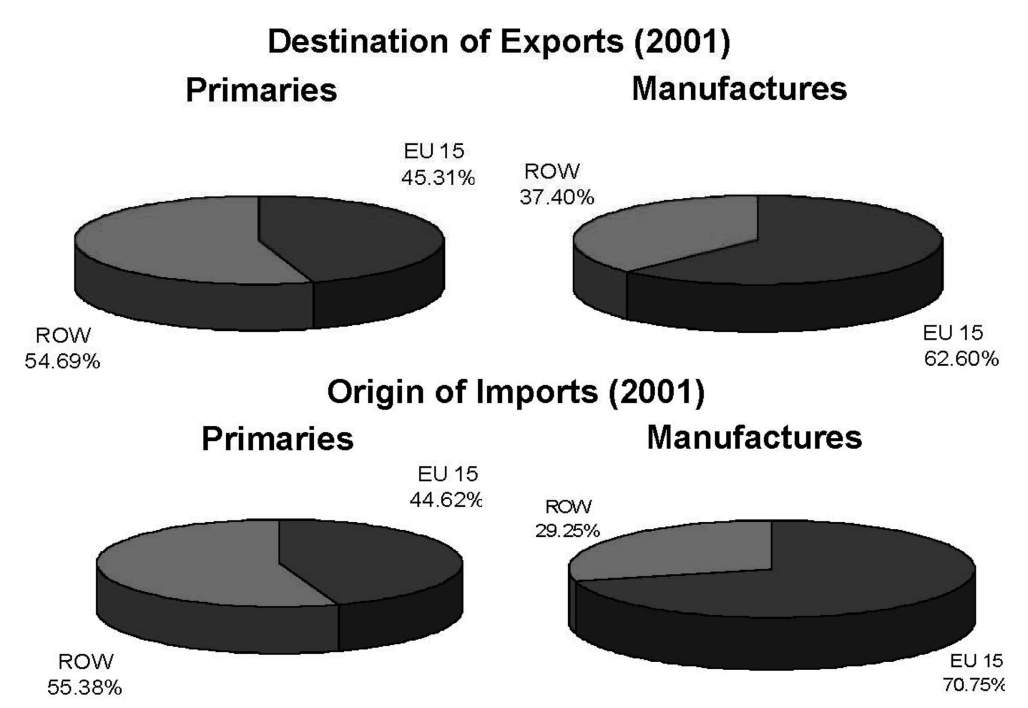

Source: Statistical Office of the Republic of Slovenia 
of these trade liberalization reforms on the different productive sectors of Ecuador's and Slovenia's economies. Therefore, an important factor in this analysis is finding the correct level of sectoral disaggregation. We used a variety of criteria (i.e., the relative importance of the sector in the total economy, the level of tariff protection that the sector enjoys, the relative importance of the sector in the total imports or exports, and so on), to determine the number of sectors. The sectoral disaggregation we choose for Ecuador and Slovenia is the following:

The model presented in the next section is flexible enough that it allows us to use a finer or coarser level of disaggregation than the one we have chosen here, in case a specific sector needs to be highlighted or a more compact aggregation is desired.

\section{Social Accounting Matrices}

Once the relevant sectoral decomposition is defined, Social Accounting Matrices (SAM) for Ecuador and Slovenia have to be constructed. Social Accounting Matrix is a record of all the transactions that take place in an economy during a particular period as it represents flows of all economic transactions taking place within an economy by all institutional agents (Production, Consumption, Government and Foreign trade partners). The period referred in Social Accounting Matrices is

Figure 6. Tariff Schedules of Slovenia and European Union.

Tariff Rates

Slovenia and European Union

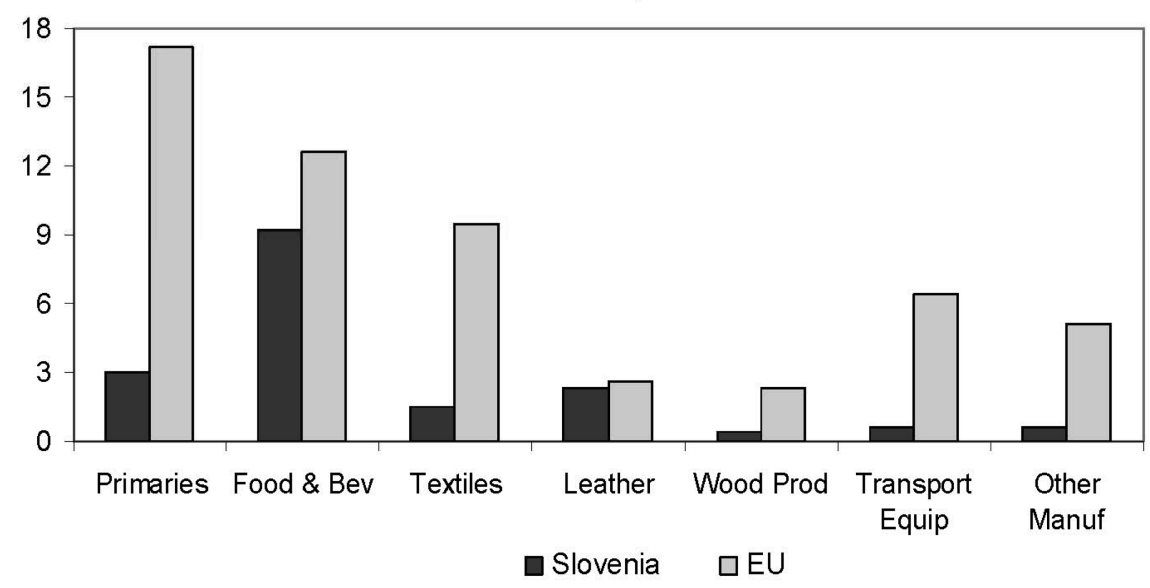

Source: World Trade Organization, Trade Policy Reviews 
usually a one-year period, providing a static "snapshot" of the economy. They are constructed to have equal number of columns and rows in the sense that all institutional agents act as both buyers and sellers: column labels represent those who made expenditure and row labels represent those who received it. A general introduction to Social Accounting Matrices and its applications are shown in Pyatt and Round (1985). The SAMs we construct are crucial elements for the numerical specification of the model described in the following section.

Input-Output tables are the main source for constructing each Social Accounting Matrix as they contain the data for all the inter-industry transactions taking place in the economy for a given year as well as all payments to factors of production and final demand for goods. For Ecuador, we use the most recently available InputOutput table, which is from 2001. This table contains 47 industries and 47 products. Other data sources are the Foreign Trade Statistics, produced by the Central Bank of Ecuador. The analysis for Slovenia uses the Input-Output table from 2001 because it is likewise the most recently available one. This table consists of 60 industries and 60 products. Other data sources that we use are the Foreign Trade Statistics and the Trade in Services Statistics, produced by the Statistical Office of the Republic of Slovenia and the Bank of Slovenia.

Additional statistical sources could be used if a finer level of disaggregation is desired. For example, if we wanted to measure the effects of these trade liberalization reforms on the different types of households (rural versus urban, high skilled versus low skilled), we could use the national household income and expenditure surveys to disaggregate the households. At this point, however, we do not conduct such decomposition. Cho and Díaz (2008) use Slovenia Household Surveys to analyse the distributional impact of trade reforms by disaggregating households by income, age, and skill intensity.

\section{The Model}

The model is a standard static applied general equilibrium model that follows the tradition of Shoven and Whalley (1984). In these static applied general equilibrium models, there are several agents in the economies of Ecuador and Slovenia: households, producers (firms), a domestic government, and foreign trade partners. For Ecuador, we consider the United States, the Andean Community, and the rest of the world as its trade partners. For Slovenia, the European Union (which includes the 15 members that belonged to the Union before the May 2004 
Table 2.1. Sectoral Disaggregation for Ecuador and Slovenia

\begin{tabular}{ll}
\hline \multicolumn{1}{c}{ Ecuador } & \multicolumn{1}{c}{ Slovenia } \\
\hline Bananas & Primary Goods \\
Cereals & Food and Beverages \\
Flowers & Leather \\
Petroleum (Crude Oil) & Wood and Furniture \\
Other Primary Goods & Textiles \\
Shrimp & Transportation Equipment \\
Textiles & Other Manufactures \\
Chemical Products & Services \\
Transportation Equipment & \\
Other Manufactures & \\
Services & \\
\hline
\end{tabular}

expansion plus the new 9 members) and the rest of the world are considered as trade partners. For notational purposes, we will denote by $\mathrm{T}$ the set of trade partners for each economy. We describe the main features of the agents in detail.

\section{A. Domestic Production Firms}

We assume that the final goods are produced combining a locally-produced component and an imported component. The domestic production firms produce the domestic component of the final goods. They use intermediate inputs from all sectors in fixed proportions, and also combine capital and labor using a CobbDouglas technology for output. The production function of the domestic firm producing $\operatorname{good} j$ is:

$$
y_{i, d}=\min \left\{x_{1, j}^{d} / a_{1, j}^{d}, \ldots, x_{j, j}^{d} / a_{j, j}^{d}, \ldots, x_{n, j}^{d} / a_{n, j}^{d}, \beta_{j} k_{j}^{\alpha} l_{j}^{\left(1-\alpha_{j}\right)}\right\}
$$

where $\{1, \ldots, j, \ldots, n\}$ are the goods in $G_{p}$, the set of the production goods; $y_{j, d}$ is the output of domestic firm $j, x_{i, j}^{d}$ is the amount of intermediate inputs of good $i$ used in the production of good $j ; a_{i, j}^{d}$ is the unit input requirement of good $i$ in the production of good $j$; and $k_{j}$ and $l_{j}$ are the capital and labor inputs used to produce $\operatorname{good} j$. The price of the domestic good $j$ will be denoted by $p_{j, d}$.

\section{B. Final Production Goods Firms}

The firm that produces the final production good $j$ combines the domestic component produced by the domestic production firms with imported goods using an Armington aggregator of the form: 


$$
y_{j}=\gamma_{j}\left[\delta_{j, d} y_{j, d}^{\rho_{m, j}}+\sum_{f \in T} \delta_{j, f} y_{j, d}^{\rho_{m, j}}\right]^{\frac{1}{\rho_{m, j}}}
$$

where $\sigma_{m, j}=1 /\left(1-\rho_{m, j}\right)$ is the constant elasticity of substitution between domestic and imported goods (note that we allow for possibly different elasticities of substitution for different goods), $y_{j}$ is the output of final good $j, y_{j, d}$ is the domestic component of final good $j$, and $y_{j, f}$ is the imported component from each of the trade partners. Note that, when $\rho_{m, j} \rightarrow 0$, the production function takes the usual Cobb-Douglas form, i.e., $y_{j}=\gamma_{j}\left[y_{j, d}^{\delta_{j}, d} \times \prod_{f \in T} y_{j, f}^{\delta_{j, i}}\right]$.

Finally, imports of good $j$ from country $f$ are subject to and ad-valorem tariff rate $\tau_{j, f}$. The set of production goods will be denoted by $G_{P}$ The price of final good $j$ is denoted by $p_{j}$.

\section{Consumption Goods Firms}

We assume that the goods households purchase are different goods than those that production firms trade in their inter-industry transactions. For example, the strawberries that a consumer purchases at a supermarket have a very high component of services embodied in them and are different from the strawberries purchased by a firm that produces strawberry jelly. Thus, the goods the households purchase are labelled "consumption goods" to differentiate them from the production goods. The consumption goods firms combine the final production goods using a fixed proportion technology to produce goods that will be purchased exclusively by the consumers. The production function for the consumption good $j$ firm is:

$$
y_{j}^{c}=\min \left\{x_{1, j}^{c} / a_{1, j}^{c}, \ldots, x_{j, j}^{c} / a_{j, j}^{c}, \ldots, x_{n, j}^{c} / a_{n, j}^{c}\right\}
$$

where $\{1, \ldots, j, \ldots, n\}$ are all the goods in $G_{c}$, the set of consumption goods. An additional assumption is made: $x_{i, j}^{c}=0$ for $i \neq j$, ser, that is, consumption $\operatorname{good} j$ firm only uses as inputs final goods of the same sector and services. The set of consumption goods will be denoted by $G_{c}$. The price of consumption good $j$ is denoted by $p_{c . j}$.

\section{Investment Good Firms}

Inspection of the Social Accounting Matrices reveals that agents in both the 
Ecuadorian and Slovenian economies save. The model includes an investment good to account for the savings observed in the data. In a dynamic model, agents save in order to enjoy future consumption. In our model, agents derive utility from consuming this investment good, just as they derive utility from consumption goods. The investment good, $y_{i n v}$ is produced by a firm that combines the final goods as intermediate inputs using a fixed proportions technology, as follows:

$$
y_{i n v}=\min \left\{x_{1, i n v}^{i n v} / a_{1, i n v}^{i n v}, \ldots, x_{j, i n v}^{i n v} / a_{j, i n v}^{i n v}, \ldots, x_{n, i n v}^{i n v} / a_{n, i n v}^{i n v}\right\}
$$

The price of the investment good is denoted by $p_{i n v}$

\section{E. Households}

In each country there is a representative household that derives utility from consumption goods. Additionally, we model household savings observed in the data as purchases of the investment good. The problem of the household is:

$$
\begin{gathered}
\max \sum_{j \in \mathrm{G}_{\mathrm{c}}} \theta_{c, j} \log c_{j}+\theta_{c, i n v} \log c_{i n v}+\sum_{f \in \mathrm{T}} \theta_{i n v, f} \log c_{i n v, f} \\
\text { s.t. } \sum_{j \in \mathrm{G}_{\mathrm{c}}} p_{c, j}+p_{i n v} c_{i n v}+\sum_{f \in \mathrm{T}} e_{f} \bar{p}_{f, i n v} c_{i n v, f}=\left(1-\tau_{d}\right)(w \bar{l}+r \bar{k})
\end{gathered}
$$

where $c_{j}$ is consumption of good $j, p_{c, j}$ is the price of consumption good $j$; $\tau_{d}$ is the direct tax rate; $w$ is the wage rate, $r$ is the rental rate of capital; $\bar{l}$ and $\bar{k}$ are the aggregate endowments of labor and capital, respectively.

Since this is a static setup, we model household savings as purchases of the investment good. Then, $c_{i n v}$ represents the purchases of the investment good, and $p_{i n v}$ is the price of the investment good. Additionally, if the economy is running a trade surplus with a trade partner, we model this as household purchases of a foreign investment good (i.e, domestic consumers are saving abroad). Then, $c_{i n v, f}$ represents the purchases of the investment good from foreign country $f, \bar{p}_{i n v, f}$ is its price (which we assume to be exogenous), and $e_{f}$ is the bilateral real exchange rate.

\section{F. The Government}

A look at the SAM also reveals that governments make purchases of some goods and also that they run deficits or surpluses. To account for these observations, we assume that, in the model economy, the government is another agent which enjoys utility from consuming (production) goods and the investment 
good. Purchases of these must be financed by the revenues derived from direct and indirect taxes and tariffs revenues. The problem of the government is then:

$$
\begin{gathered}
\max \sum_{i \in \mathrm{G}_{P}} \theta_{g, i} \log c_{g, i}+\theta_{g, i n v} \log c_{g, i n v} \\
\text { s.t. } \sum_{j \in \mathrm{G}_{p}} p_{i} c_{g, i}+P_{i n v} c_{g, i n v}=\tau_{d}(w \bar{l}+r \bar{k})+\sum_{j \in G_{p}} t_{p, j} P_{j, d} y_{j, d} \\
+\sum_{j \in \mathrm{G}_{\mathrm{c}}} t_{c, j} p_{c, j} y_{j}^{c}+\sum_{i \in \mathrm{T} j \in \mathrm{G}_{\mathrm{p}}} \sum_{j, i} e_{i} \bar{p}_{j, i} y_{j, i}
\end{gathered}
$$

The left-hand side of the budget constraint of the government includes the purchases of goods and the investment good. The right-hand side of the equation includes the tax and tariff revenues: the first term is the direct tax (on the households income) receipts, the second and third terms are the revenues collected from taxing the domestic firms and consumption good firms, and the last term represents the tariff revenues collected.

\section{G. Foreign Trade Partners}

Each domestic economy trades with a set of countries, T. In each trade partner country, $f \in \mathrm{T}$, there is a representative consumer that purchases imported goods $x_{j, f}$ and consumes the local good $x_{f, f}$. The problem of the foreign household in country $f$ is:

$$
\begin{gathered}
\max \left[\sum_{j \in \mathrm{G}_{\mathrm{p}}} \theta_{j, f} x_{j, f}^{\rho_{x}}+\theta_{i n v, f} x_{i n v, f}^{\rho_{x}}+\theta_{f, f} x_{f, f}^{\rho_{x}}-1\right] / \rho_{x} \\
\text { s.t } \sum_{j \in \mathrm{G}_{\mathrm{p}}}\left(1+\tau_{j}^{f}\right) p_{j} x_{j, f}+p_{i n v} x_{i n v, f}+e_{f} x_{f, f}=e_{f} I_{f}
\end{gathered}
$$

where $\tau_{j}^{f}$ is the tariff rate country $f$ imposes on the imports of good $j, \rho_{x}$ is the parameter that determines the (common) exports elasticity of substitution $\sigma_{x}$ (i.e., $\left.\sigma_{x}=1 /\left(1-\rho_{x}\right)\right), e_{f}$ is the (bilateral) real exchange rate between the domestic economy and country $f$, and $I_{f}$ is the exogenous income of the household in country $f$.

\section{H. Definition of Equilibrium}

An equilibrium for the economy described before is a set of prices for domestic goods $\left\{p_{j, d}\right\}_{j \in \mathrm{G}_{\mathrm{p}}}$, prices for final goods $\left\{p_{j}\right\}_{j \in \mathrm{G}_{\mathrm{p}}}$, price for the investment good $p_{i n v}$, prices for consumption goods $\left\{p_{c, j}\right\}_{j \in \mathrm{G}_{\mathrm{c}}}$, factor prices $w$ and $r$, bilateral real 
exchange rates $\left\{e_{f}\right\}_{f \in \mathrm{T}}$, foreign prices $\left\{\bar{p}_{f, j}\right\}_{j \in \mathrm{G}_{\mathrm{p}}, f \in \mathrm{T}}$, a consumption plan for households $\left\{c_{j}, c_{i n v}, c_{i n v, f}\right\}_{j \in \mathrm{G}_{c}, f \in \mathrm{T}}$, a consumption plan for the government $\left\{c_{g, j}\right\}_{j \in \mathrm{G}_{\mathrm{p}}}$ and $c_{g, i n v}$, a consumption plan for the household in country $f\left\{x_{j, f}\right\}_{j \in \mathrm{G}_{\mathrm{p}}}$, $x_{i n v, f}$ and $x_{f, f}$, a production plan for the domestic good $j$ firm $\left(y_{j, d}, x_{1, j}^{d}, \ldots, x_{n, j}^{d}, k_{j}, l_{j}\right)$, a production plan for the final good $j$ firm $\left(y_{j}, y_{j, d},\left\{y_{j, f}\right\}_{f \in \mathrm{T}}\right)$, a production plan for the investment good firm $\left(y_{i n v}, x_{1, i n v}^{i n v}, \ldots, x_{n, i n v}^{i n v}\right)$, a production plan for the consumption good $j$ firm $\left(y_{j}^{c}, x_{1, j}^{c}, \ldots, x_{n, j}^{c}\right)$, such that, given tax rates and tariff rates:

- The consumption plan $\left\{c_{j}, c_{i n v}, c_{i n v, f}\right\}_{j \in \mathrm{G}_{c}, f \in \mathrm{T}}$, solves the problem of the household.

- The consumption plan $\left\{c_{g, j}\right\}_{j \in \mathrm{G}_{\mathrm{p}}}, c_{g, i n v}$ solves the problem of the government.

- The consumption plan $\left\{x_{j, f}\right\}_{j \in \mathrm{G}_{\mathrm{p}}}, x_{i n v, f}, x_{f, f}$ solves the problem of the representative household of country $f$.

- The production plan $\left(y_{j, d}, x_{1, j}^{d}, \ldots, x_{n, j}^{d}, k_{j}, l_{j}\right)$ satisfies

$$
\begin{gathered}
y_{j, d}=\min \left\{\frac{x_{1, j}^{d}}{a_{1, j}^{d}}, \ldots, \frac{x_{j, j}^{d}}{a_{j, j}^{d}}, \ldots, \frac{x_{n, j}^{d}}{a_{n, j}^{d}}, \beta_{j} k_{j}^{\alpha_{j}} l_{j}^{\left(1-\alpha_{j}\right)}\right\} \\
\left(1+t_{p, j}\right) p_{j, d} y_{j, d}-\sum_{i \in \mathrm{G}_{\mathrm{p}}} p_{i} x_{i, j}^{d}-w l_{j}-r k_{j} \leq 0,=0 \text { if } y_{j, d}>0
\end{gathered}
$$

- The production plan $\left(y_{j}, y_{j, d},\left\{y_{j, f}\right\}_{f \in \mathrm{T}}\right)$ satisfies

$$
p_{j} y_{j}-p_{j, d} y_{j, d}-\sum_{i \in T}\left(1+\tau_{j, f}\right) e_{f} \bar{p}_{f} y_{j, f} \leq 0,=0 \text { if } y_{j}>0
$$

where $y_{j, d}$ and $\left\{y_{j, f}\right\}_{f \in \mathrm{T}}$ solve

$$
\begin{gathered}
\min \left(1+t_{p, j}\right) p_{j, d} y_{j, d}+\sum_{i \in T}\left(1+\tau_{j, f}\right) e_{f} \bar{p}_{f} y_{j, f} \\
\text { s.t } \quad \gamma_{j}\left\lfloor\delta_{j, d} y_{j, d}^{\rho_{m}}+\sum_{i \in T} \delta_{j, i} y_{j, i}^{\rho_{m}}\right\rfloor^{1 / \gamma_{m}}=y_{j}
\end{gathered}
$$

- The production plan $\left(y_{i n v}, x_{1, i n v}^{i n v}, \ldots, x_{n, i n v}^{i n v}\right)$ satisfies

$$
\begin{gathered}
y_{i n}=\min \left[\frac{x_{1, i n v}^{i n v}}{a_{1, i n v}^{i n v}}, \ldots, \frac{x_{j, i n v}^{i n v}}{a_{j, i n v}^{i n v}}, \ldots, \frac{x_{n, i n v}^{i n v}}{a_{n, i n v}^{i n v}}\right] \\
p_{i n v} y_{i n v}-\sum_{i \in \mathrm{G}_{\mathrm{p}}} p_{i} x_{i, i n v}^{i n v} \leq 0,=0 \text { if } y_{i n v}>0
\end{gathered}
$$


- The production plan $\left(y_{j}^{c}, x_{1, j}^{c}, \ldots, x_{n, j}^{c}\right)$ satisfies

$$
\begin{gathered}
y_{j}^{c}=\min \left[\frac{x_{1, j}^{c}}{a_{1, j}^{c}}, \ldots, \frac{x_{j, j}^{c}}{a_{j, j}^{c}}, \ldots, \frac{x_{n, j}^{c}}{a_{n, j}^{c}}\right] \\
\left(1+t_{c, j}\right) p_{c, j} y_{j}^{c}-\sum_{i \in \mathrm{G}_{\mathrm{p}}} p_{i} x_{i, j}^{c} \leq 0,=0 \text { if } y_{j}^{c}>0
\end{gathered}
$$

- Markets clear:

$$
\begin{aligned}
& \circ y_{j}=\sum_{i \in G_{p}} x_{j, i}^{d}+\sum_{i \in \mathrm{G}_{\mathrm{c}}} x_{j, i}^{c}+x_{j, i n v}^{i n v}+c_{g, j}+\sum_{f \in t} x_{j, f} \\
& \circ y_{j}^{c}=c_{j} \\
& \circ y_{i n v}=c_{i n v}+c_{g, i n v}+\sum_{f \in t} x_{i n v, f} \\
& \circ \sum_{j \in G_{p}} l_{j}=\bar{l}, \sum_{j \in G_{p}} k_{j}=\bar{k}
\end{aligned}
$$

- The balance of payments condition is satisfied:

$$
e_{f} \sum_{j \in G_{p}}\left(1+\tau_{j, f}\right) \bar{p}_{f, j} y_{j, f}+e_{f} \bar{p}_{i n v, f} c_{i n v, f}=\sum_{j \in G_{p}}\left(1+\tau_{j}^{f}\right) p_{j} x_{j, f}+p_{i n v} x_{i n v, f} \quad \forall f \in T
$$

\section{Data and Calibration}

Given our data availability, we calibrate the parameters of the model such that, in equilibrium, the institutional agents of the model replicate the same transactions that their counterparts in the real world undertake according to the Social Accounting Matrix. ${ }^{1}$ A detailed explanation for the usage of applied general equilibrium models and procedures for calibration is shown in Kehoe (1996). Most of the parameters can be directly calibrated from the SAM. The Appendix contains the values of the calibrated parameters in the model economies as well as the Social Accounting Matrices of Ecuador and Slovenia. For those parameters that cannot be explicitly calibrated from the data, we explain how we assign those values.

Trade Partners' Income: The incomes of the trade partners are extracted from the International Financial Statistics published by the International Monetary Fund.

${ }^{1}$ A more elaborate work would involve using a time series of Social Accounting Matrices and conducting a statistical estimation of the parameters as specified in Jorgenson (1984). 
Tariff Rates: The tariff rates that Ecuador and Slovenia impose on the imports from their trade partners are extracted implicitly from the Input-Output tables. In that sense, the tariff rates that we calibrate are effective tariff rates rather than nominal rates. We make the additional assumption that Ecuador imposes a tariff rate of zero on all imports that originate from the Andean Community (since Ecuador is a member of this trading bloc). To determine the tariff rates that the trading partners impose on imports from Ecuador or Slovenia, the most recent editions of the Trade Policy Reviews by the World Trade Organization are used. The tariff rates imposed by Ecuador and the United States are shown in Table 4.1, while the tariff rates imposed by Slovenia and the European Union are shown in Table 4.2. To determine the tariff rates imposed by the "rest of the world", we assume that, for Ecuador, the tariffs of the rest of the world are a simple average of the tariffs imposed by the European Union and Japan; for Slovenia, the tariffs from the rest of the world are a simple average of the tariffs imposed by Japan and the United States.

Elasticities of Substitution: Given the static nature of our model, the elasticities of substitution for exports and imports cannot be calibrated directly from the InputOutput tables. Instead, we use different sets of values for these parameters. For our "benchmark" case, we set $\rho_{m, j}=0.8 \forall j \in \mathrm{G}_{\mathrm{p}}$, and $\rho_{x}=0.9$, which imply that the elasticities of import and export substitution are 5 and 10 , respectively. Additionally, we take two sets of values from the literature, one from Hummels (2001) and the other from Rolleigh (2003). ${ }^{2}$ The values used are the following:

For all cases, the parameter governing the export elasticity of substitution $\rho_{x}$ is fixed to be 0.9 . Later, in section 5.6 we conduct a sensitivity analysis by changing the values of $\rho_{x}$.

\section{Results and Numerical Experiments}

This section presents the results from the "benchmark" simulation. For Ecuador, this implies signing a free trade agreement with the United States, while for Slovenia, this implies joining the European Union as a full-fledged member. We examine the impact of trade liberalization on consumption good prices, total domestic production, trade volume, and welfare. For welfare analysis, we construct

${ }^{2}$ Rolleigh (2003) provides estimates for elasticities of substitution for manufacturing industries only. In this case, we use the same value of $\rho_{m, j}$ for the primary goods and services used in the benchmark experiment. 
a social real income index that uses both the consumer real income index and the government real income index. ${ }^{3}$ This equivalent variation will measure how much income consumer would require under the base prices in order to achieve the same level of utility as in the base simulation.

Next, with the benchmark simulation as a reference, we conduct five numerical experiments, each of which explores the implications on prices, production, trade, and welfare. First, we look at a case that we label as "partial" liberalization. In reality, trade liberalizations take place over a transition period. For example, the countries involved follow a carefully sequenced time agenda where they gradually lower tariff rates. We assume that the tariff rates on all primary and manufactured goods are uniformly set to $2 \%$ for the case of Ecuador and to $1 \%$ for the case of Slovenia, and we report the impact of this intermediate step on prices, allocations, and welfare.

Second, in the benchmark numerical experiment, all the elasticities of substitution (for both imports and exports) were assumed to be the same across sectors. We now analyze how the benchmark results would change when we allow for import elasticities of substitution that are different across sectors. For sectoral import elasticities, we take estimated numbers from Rolleigh (2003) and Hummels (2001) as shown in Table 4.5 and 4.6, respectively.

Third, we realize that tariff revenues are an important source of government revenue in Ecuador. This tends to be true in developing countries, where tariffs serve both as a protectionist measure as well as a source of government funding. Since a free trade agreement with the United States implies an important loss of tariff revenues, we look at a possible government policy aimed to compensate for this loss. Specifically, we ask by how much the value added tax (VAT) must be raised in order to offset the loss in the tariff revenue and keep the government balance constant. We determine the effective VAT rate in the actual data from the Input-Output table and estimate the corresponding VAT rate for the benchmark economy as well as for the cases of partial liberalization and sector-by-sector import elasticities.

In our fourth experiment, we notice that, by joining the European Union, Slovenia must adopt a tariff schedule that is more protectionist than the one it

\footnotetext{
${ }^{3}$ The consumer real income index is given by $\Pi_{j} c_{j}^{\theta_{j}}$, where $j$ ranges over the consumption goods and the investment good. The government real income index is given by $\Pi_{j} c_{g, j}^{\theta_{g, j}}$, where $j$ ranges over the production goods and the investment good consumed by the government. The social real income index is defined as $\Pi_{j} C_{j}^{\Theta_{j}}$, where $C_{j}=c_{j}+c_{g, j}$ and $\Theta_{j}=\left(c_{j}+c_{g, j}\right) /\left(\Sigma_{j} c_{j}+\Sigma_{j} c_{g, j}\right)$.
} 
Table 4.1. Tariff Rates - Ecuador vs. United States

(unit:\%)

\begin{tabular}{lcc}
\hline \multicolumn{1}{c}{ Sectors } & Ecuador & United States \\
\hline Bananas & 0.0 & 6.3 \\
Cereals & 13.4 & 1.5 \\
Flowers & 1.3 & 1.5 \\
Petroleum & 0.0 & 2.2 \\
Other Primaries & 9.4 & 9.7 \\
Shrimp & 22.2 & 2.0 \\
Textiles & 16.1 & 9.0 \\
Chemicals & 6.1 & 3.7 \\
Transport & 16.4 & 2.6 \\
Other Manufactures & 7.0 & 4.0 \\
Services & 0.0 & 0.0 \\
\hline
\end{tabular}

previously had. This is especially important for the case of primary goods, which Slovenia mainly imports from countries outside the European Union. Hence, our experiment looks at the hypothetical case of Slovenia signing a free trade agreement with the European Union instead of joining the European Union, implying that Slovenia retains its tariff schedule with the rest of the world. This experiment could provide a useful comparison on the different types of trade liberalization.

Finally, in our last numerical experiment, we perform a sensitivity analysis to look at the relationship between different values of the export elasticity of substitution $\left(\sigma_{x}\right)$ and the country's welfare from the trade liberalization. Specifically, we test the hypothesis argued by Johnson (1954) which documents the relationship between the elasticity of export substitution and the optimal tariff.

\section{A. Benchmark Results}

Table 4.2. Tariff Rates - Slovenia vs. European Union

(unit:\%)

\begin{tabular}{lcc}
\hline \multicolumn{1}{c}{ Sectors } & Slovenia & European Union $(\%)$ \\
\hline Primary & 3.0 & 17.2 \\
Food \& Beverages & 9.2 & 12.6 \\
Textiles & 1.5 & 9.5 \\
Leather & 2.3 & 2.6 \\
Wood Products & 0.4 & 2.3 \\
Transport & 0.6 & 6.4 \\
Other Manufactures & 0.6 & 5.1 \\
Services & 0.0 & 0.0 \\
\hline
\end{tabular}


Table 4.3. Ecuador Import Elasticities of Substitution $\left(\rho_{m, j}\right)$

\begin{tabular}{lcc}
\hline \multicolumn{1}{c}{ Sectors } & Hummels (2001) & Rolleigh (2003) \\
\hline Bananas & 0.59 & 0.80 \\
Cereals & 0.82 & 0.80 \\
Flowers & 0.59 & 0.80 \\
Petroleum & 0.82 & 0.80 \\
Other Primaries & 0.80 & 0.80 \\
Shrimp & 0.79 & 0.95 \\
Textiles & 0.84 & 0.93 \\
Chemicals & 0.82 & 0.77 \\
Transport & 0.86 & 0.91 \\
Other Manufactures & 0.81 & 0.91 \\
Services & 0.80 & 0.80 \\
\hline
\end{tabular}

\section{(1) Consumption Good Prices}

Table 5.1 below shows the percent change in the price of consumption goods after Ecuador and the United States signed a free trade agreement and Slovenia's joining of the European Union. For Ecuador, the largest decline in prices takes place in the transport sector by a margin of $1.35 \%$. All other main import sectors (cereals, textiles, chemicals, and other manufactures) record decreases in their prices. On the other hand, for Slovenia, the largest decline in prices takes place in the leather and food and beverages sectors, falling by more than 1 percent. The main import sector, which is the transport sector, also shows a price decline of $0.90 \%$. However, the primary goods sector, which is another main import sector, records a price increase of $0.54 \%$. This increase in the price of primary goods may likely be a result of trade diversion from joining the European Union with the magnitude of trade diversion shown in section 5.1.3.

In addition, while Ecuador's economy has a clear distinction of import versus

Table 4.4. Slovenia Import Elasticities of Substitution $\left(\rho_{m, j}\right)$

\begin{tabular}{lcc}
\hline \multicolumn{1}{c}{ Sectors } & Hummels (2001) & Rolleigh (2003) \\
\hline Primary & 0.77 & 0.80 \\
Food \& Beverages & 0.79 & 0.95 \\
Textiles & 0.84 & 0.93 \\
Leather & 0.89 & 0.93 \\
Wood Products & 0.74 & 0.91 \\
Transport & 0.86 & 0.91 \\
Other Manufactures & 0.82 & 0.90 \\
Services & 0.80 & 0.80 \\
\hline
\end{tabular}


Table 5.1. Effect of Trade Liberalization on Consumption Good Prices

(unit: \%)

\begin{tabular}{lclc}
\hline \multicolumn{1}{c}{ (Ecuador) } & \multicolumn{2}{c}{ (Slovenia) } \\
\hline \multicolumn{1}{c}{ Sector } & Price Change & \multicolumn{1}{c}{ Sector } & Price Change \\
\hline Bananas & 0.42 & Primary & 0.54 \\
Cereals & -0.57 & Food \& Beverages & -1.06 \\
Flowers & 0.53 & Textiles & -0.30 \\
Petroleum & - & Leather & -1.25 \\
Other Primaries & 0.28 & Wood Products & 0.26 \\
Shrimp & 0.51 & Transport & -0.90 \\
Textiles & -0.12 & Other Manufactures & 0.03 \\
Chemicals & -0.23 & Services & 0.67 \\
Transport & -1.35 & & \\
Other Manufactures & -0.42 & & \\
Services & 0.44 & & \\
\hline
\end{tabular}

export sectors, for Slovenia, most sectors are both import and export intensive. This may add to the fact that the sectoral impacts are harder to distinguish for Slovenia than for Ecuador.

\section{(2) Domestic Production}

Table 5.2 below shows the percent change in the total domestic production for Ecuador and Slovenia. For Ecuador, the largest increase in domestic production takes place in the banana sector with an increase of $14.07 \%$. Other main export sectors (petroleum, shrimp, and flowers) record positive gains in domestic production. The sectoral shift in domestic production from trade liberalization is evident in the case of Ecuador as all the export-intensive sectors experience higher production at the expense of the rest of the economic sectors. For Slovenia, the biggest beneficiary in terms of domestic production is the textiles sector, where production increases by $31.41 \%$, followed by the transport sector, which shows an increase of $21.83 \%$. Comparing the production of the top export sector of the two countries, Slovenia benefits more as the production of the transport sector increases by more than 20 percent whereas the production of petroleum sector in Ecuador increases by approximately 1 percent.

\section{(3) International Trade}

Tables 5.3 and 5.4 show the percent change in exports and imports for Ecuador and Slovenia. For Ecuador, the average exports and imports of all primary and manufactured goods with the United States increase by $34.80 \%$ and $46.23 \%$, respectively. Hence, the share of Ecuador's exports to the United States increases from $38.09 \%$ to $45.87 \%$, while the share of Ecuador's imports from the United 
Table 5.2. Effect of Trade Liberalization on Domestic Production

(unit: \%)

\begin{tabular}{lclc}
\hline \multicolumn{1}{c}{ (Ecuador) } & \multicolumn{2}{c}{ (Slovenia) } \\
\hline Sector & Quantity Change & \multicolumn{1}{c}{ Sector } & Quantity Change \\
Cereals & 14.07 & Primary & 1.12 \\
Flowers & -9.29 & Food \& Beverages & -4.00 \\
Petroleum & 2.92 & Textiles & 31.41 \\
Other Primaries & 1.11 & Leather & -2.59 \\
Shrimp & 0.81 & Wood Products & -5.14 \\
Textiles & 4.57 & Transport & 21.83 \\
Chemicals & -0.86 & Other Manufactures & 5.06 \\
Transport & -2.29 & Services & -2.28 \\
Other Manufactures & -4.08 & & \\
Services & -1.67 & & \\
\hline
\end{tabular}

States increases from $23.62 \%$ to $31.59 \%$. On a disaggregate level, the exports to the United States increase in every sector, with the largest gain shown in the banana sector with an increase of around $77 \%$. All four main export sectors (banana, shrimp, petroleum, and flower sectors) show a strong increase of $9 \%$ or more. In contrast, the exports to the rest of the world decrease by around 2\%. Imports from the United States in the transport sector, which is the largest import sector, record an significant increase of around $87 \%$. Other main import sectors such as cereals, textiles and chemicals show an increase of more than $30 \%$. Just as with exports, imports from the rest of the world decrease for all main import sectors, except for the textiles and other primaries sectors which showed small increase of around $2 \%$ to $4 \%$. In terms of total quantity, the imports to the rest of the world decrease by $2 \%$. As for Slovenia's trade with the European Union, total exports and imports of goods increase by $46.71 \%$ and $31.63 \%$, respectively. As for the composition of goods trade by destination, the share of Slovenia's export to the European Union increases from $77.42 \%$ to $83.61 \%$, while the share of import from the European Union rises from $68.59 \%$ to $77.13 \%$. On a sectoral level, the largest increase in exports to the European Union takes place in the primary goods sector, followed by food and beverages and textiles sectors. This reflects the high trade barriers set by the European Union in those sectors before Slovenia joined the customs union. Exports and imports of transport equipments to European Union, which is the largest trade sector in Slovenia, increase by around $66 \%$ and $40 \%$, respectively. Similarly, the imports from the European Union increased the most in the food and beverages sector, followed by the textiles sector. As for trade with the rest of the 
Table 5.3. Effect of Trade Liberalization on Main Exports

(unit: \%)

\begin{tabular}{lrrlrr}
\hline & (Ecuador) & \multicolumn{4}{c}{ (Slovenia) } \\
\hline \multicolumn{1}{c}{ Sector } & \multicolumn{1}{c}{ US } & \multicolumn{1}{c}{ ROW } & \multicolumn{1}{c}{ Sector } & EU & \multicolumn{1}{c}{ ROW } \\
\hline Bananas & 76.66 & -6.34 & Primary & 214.00 & -15.13 \\
Flowers & 9.65 & -7.73 & Food \& Beverages & 201.11 & 4.48 \\
Petroleum & 15.26 & -9.52 & Textiles & 105.60 & -5.26 \\
Other Primaries & 147.58 & -4.29 & Leather & 20.25 & 6.22 \\
Shrimp & 15.00 & -7.86 & Wood Products & -1.81 & -10.69 \\
& & & Transport & 65.92 & 1.89 \\
& & & Other Manufactures & 35.24 & -6.45 \\
\hline
\end{tabular}

Table 5.4. Effect of Trade Liberalization on Main Imports

(unit: \%)

\begin{tabular}{lrrlcr}
\hline & (Ecuador) & \multicolumn{4}{c}{ (Slovenia) } \\
\hline \multicolumn{1}{c}{ Sector } & \multicolumn{1}{c}{ US } & \multicolumn{1}{c}{ ROW } & \multicolumn{1}{c}{ Sector } & EU & \multicolumn{1}{c}{ ROW } \\
\hline Cereals & 73.48 & -6.52 & Primary & 37.07 & -37.58 \\
Other Primaries & 60.84 & 3.91 & Food \& Beverages & 69.26 & -12.67 \\
Textiles & 112.06 & 1.91 & Textiles & 60.94 & -4.32 \\
Chemicals & 32.25 & -0.44 & Leather & 24.48 & 2.47 \\
Transport & 87.15 & -11.37 & Wood Products & 12.40 & -6.11 \\
Other Manufactures & 4.83 & -0.42 & Transport & 39.50 & -4.41 \\
& & & Other Manufactures & 24.45 & -9.69 \\
\hline
\end{tabular}

world, imports suffered the most, falling by approximately $12 \%$, whereas the total exports to the rest of the world fell by around 5\%. Compared to the case of Ecuador, trade diversion is more evident in the case of Slovenia, especially in the imports. On a disaggregate level, imports from the rest of the world in the primary goods falls by around $38 \%$ as a result of higher tariff rated Slovenia adopts upon its accession to the European Union.

(4) Welfare

Finally, we examine the impact of the trade liberalization on national welfare. For Ecuador, the government's tariff revenue falls by $31 \%$ after signing the free trade agreement with the United States. This revenue loss is reflected in the

Table 5.5. Effect of Trade Liberalization on Welfare

(unit:\%)

\begin{tabular}{lcc}
\hline \multicolumn{1}{c}{ Institution } & Ecuador & Slovenia \\
\hline Consumer Welfare & 0.90 & 1.37 \\
Government Welfare & -4.36 & 2.85 \\
Social Welfare & 0.21 & 1.66 \\
\hline
\end{tabular}


decline in the government welfare, which fell approximately $4 \%$. However, the consumer's welfare gain offsets the government's welfare loss, and the overall social welfare shows a slight increase of $0.21 \%$. In Slovenia, on the other hand, the tariff revenue increases by around $4 \%$ as the country adopts the protectionist tariff policy of the European Union. This explains why the government welfare increases in Slovenia, as opposed to the decrease observed in Ecuador. In addition, the magnitude of consumer welfare gain is larger than Ecuador indicating that the benefits of gaining free access to the European Union market may be greater than the costs of trade diversion under the adoption of European Union's protectionist tariff policy. The overall social welfare also shows an increase of $1.66 \%$, as shown in Table 5.5.

\section{B. Partial Liberalization}

\section{(1) Consumption Good Prices}

Table 5.6 below shows the percent change in the price of consumption goods after Ecuador and the United States bilaterally lower the tariff rates to a uniform level of $2 \%$ on all primary and manufactured goods and Slovenia and the European Union decide to lower the tariff to a uniform $1 \%$ rate, while retaining its tariff rates toward the rest of the world. For Ecuador, this "partial" liberalization can be interpreted as an intermediate step before complete tariff removal, while for Slovenia this can correspond to partial removal of tariffs prior to adopting the common tariff policy of the European Union. While the tariff imposed by the

Table 5.6. Effect of Partial Liberalization on Consumption Good Prices

(unit:\%)

\begin{tabular}{|c|c|c|c|}
\hline \multicolumn{2}{|c|}{ (Ecuador) } & \multicolumn{2}{|c|}{ (Slovenia) } \\
\hline Sector & Price Change & Sector & Price Change \\
\hline Bananas & 0.30 & Primary & -0.14 \\
\hline Cereals & -0.45 & Food \& Beverages & -1.06 \\
\hline Flowers & 0.27 & Textiles & -0.37 \\
\hline Petroleum & - & Leather & -0.77 \\
\hline Other Primaries & 0.16 & Wood Products & 0.32 \\
\hline Shrimp & 0.32 & Transport & -0.53 \\
\hline Textiles & -0.14 & Other Manufactures & 0.03 \\
\hline Chemicals & -0.12 & Services & 0.65 \\
\hline Transport & -1.09 & & \\
\hline Other Manufactures & -0.26 & & \\
\hline Services & 0.30 & & \\
\hline
\end{tabular}


European Union decreases from this intermediate measure, the tariff rate imposed by Slovenia increases for some manufacturing sectors such as wood products, transport, and other manufacturing sectors. Since most free trade agreements follow a gradual transition, this simulation can shed light on the intermediate effects of trade liberalization. For Ecuador, the quantitative effects are generally smaller in magnitude compared to the full liberalization case, but the qualitative implications follow the same direction. The largest decline in prices takes place in the transport sector by a margin of $1.09 \%$, which is approximately 81 percent the level achieved under the benchmark scenario. On the other hand, for Slovenia, while the largest decline in prices takes place in the leather and food and beverages sectors, there is a decrease in the consumption good prices in the primary sector in contrast to the full membership benchmark case.

\section{(2) Domestic Production}

Table 5.7 below shows the percent change in the total domestic production for Ecuador and Slovenia under the partial liberalization scenario. For Ecuador, the largest increase in domestic production takes place in the banana sector with increases of $10.42 \%$, which is around 74 percent the magnitude achieved under the full liberalization simulation. For other main export sectors, petroleum and flowers sectors record declines in domestic production, while the shrimp sector now grows by a modest margin. All other domestic sectors show decrease in production, indicating that the sectoral shift takes place only in favor of the banana sector, not to all export sectors. For Slovenia, the biggest beneficiary in terms of domestic production is still the textiles sector, with increase of $28.22 \%$, which is 90 percent

Table 5.7. Effect of Partial Liberalization on Domestic Production

(unit:\%)

\begin{tabular}{lclc}
\hline \multicolumn{1}{c}{ Sector } & Quantity Change & \multicolumn{1}{c}{ Sector } & Quantity Change \\
\hline Bananas & 10.42 & Primary & -2.07 \\
Cereals & -6.65 & Food \& Beverages & -2.02 \\
Flowers & -1.20 & Textiles & 28.22 \\
Petroleum & -0.36 & Leather & -3.03 \\
Other Primaries & 0.98 & Wood Products & -6.06 \\
Shrimp & 0.16 & Transport & 16.11 \\
Textiles & -0.55 & Other Manufactures & 4.01 \\
Chemicals & -1.25 & Services & -1.79 \\
Transport & -3.22 & & \\
Other Manufactures & -0.83 & & \\
Services & -0.16 & & \\
\hline
\end{tabular}


of the level under full liberalization, followed by the transport sector with increase of $16.11 \%$, which is 74 percent the magnitude under the full membership simulation.

\section{(3) International Trade}

Tables 5.8 and 5.9 show the percent change in exports and imports for Ecuador and Slovenia. For Ecuador, on average, the total exports and imports of all primary and manufactured goods with the United States increase by $20.59 \%$ and $29.16 \%$, respectively, which are around 60 percent the levels under the full liberalization case. In contrast, the exports and imports with the rest of the world decreased by $1.34 \%$ and $1.40 \%$, which are approximately 30 percent lower than the decrease observed under the benchmark scenario. As with the case of full liberalization, trade diversion for Ecuador is relatively negligible.

On the other hand, for Slovenia, total exports and imports of goods with the European Union increase by $39.97 \%$ and $21.70 \%$, respectively, which are around 70 percent the level achieved under the joining the European Union as a full member. In contrast to the benchmark scenario, the trade with the rest of the world

Table 5.8. Effect of Partial Liberalization on Main Exports

(unit:\%)

\begin{tabular}{lrrlrr}
\hline & (Ecuador) & \multicolumn{4}{c}{ (Slovenia) } \\
\hline \multicolumn{1}{c}{ Sector } & \multicolumn{1}{c}{ US } & \multicolumn{1}{c}{ ROW } & \multicolumn{1}{c}{ Sector } & EU & \multicolumn{1}{c}{ ROW } \\
\hline Bananas & 57.03 & -4.87 & Primary & 221.18 & -5.86 \\
Flowers & -0.73 & -4.55 & Food \& Beverages & 179.98 & 18.47 \\
Petroleum & 5.34 & -5.47 & Textiles & 92.88 & 8.38 \\
Other Primaries & 120.01 & -2.76 & Leather & 5.12 & 13.24 \\
Shrimp & 3.62 & -5.13 & Wood Products & -9.76 & 0.11 \\
& & & Transport & 47.04 & 10.10 \\
& & & Other Manufactures & 23.88 & 4.50 \\
\hline
\end{tabular}

Table 5.9. Effect of Partial Liberalization on Main Imports (unit:\%)

\begin{tabular}{lcrlrr}
\hline \multicolumn{1}{c}{ (Ecuador) } & \multicolumn{4}{c}{ (Slovenia) } \\
\hline \multicolumn{1}{c}{ Sector } & US & \multicolumn{1}{c}{ ROW } & \multicolumn{1}{c}{ Sector } & EU & \multicolumn{1}{c}{ ROW } \\
\hline Cereals & 55.39 & -4.51 & Primary & 23.03 & -0.74 \\
Other Primaries & 39.83 & 2.96 & Food \& Beverages & 60.76 & -2.99 \\
Textiles & 84.94 & 1.31 & Textiles & 46.78 & 27.74 \\
Chemicals & 16.74 & 0.19 & Leather & 16.78 & -2.60 \\
Transport & 68.21 & -9.18 & Wood Products & 4.01 & -4.46 \\
Other Manufactures & 21.78 & -0.02 & Transport & 26.15 & 14.36 \\
& & & Other Manufactures & 15.77 & 5.14 \\
\hline
\end{tabular}


Table 5.10. Effect of Partial Liberalization on Welfare

(unit:\%)

\begin{tabular}{lcc}
\hline \multicolumn{1}{c}{ Institution } & Ecuador & Slovenia \\
\hline Consumer Welfare & 0.56 & 1.15 \\
Government Welfare & -3.01 & 2.29 \\
Social Welfare & 0.10 & 1.38 \\
\hline
\end{tabular}

now increases modestly, with exports and imports increasing by $6.30 \%$ and $5.70 \%$, respectively. Looking at disaggregated sectors, trade diversion disappears or is at most marginal. For example, in the primary goods sector, imports from the rest of the world are almost unchanged compared to 38 percent decline observed under the benchmark scenario. Sectors such as textiles and transport sectors now experience large gains in imports from the rest of the world. This is due to the fact that under the partial liberalization scenario, Slovenia still retains its own tariff policy against the rest of the world and only adjusts tariff rates with the European Union bilaterally.

(4) Welfare

Finally, we examine the impact of the partial liberalization on national welfare. For Ecuador, the government tariff revenue declines by $22 \%$, which is around 71 percent of the benchmark case, contributing to a 3 percent decline in government welfare. Given the smaller reduction in tariffs, the consumer welfare gain is weaker under the partial liberalization scenario. Overall social welfare gain of $0.10 \%$ is approximately 48 percent the gain achieved under the full liberalization case. Looking at Slovenia, the government welfare gain is at $2.29 \%$ while consumer welfare gain stands at $1.15 \%$. The magnitude is 80 and 84 percent the level reached under the full membership of the European Union case. The overall social welfare gain under the partial liberalization is 17 percent lower than the benchmark scenario. Comparing the diminishing welfare gains under the partial liberalization in both countries, Slovenia suffers less than Ecuador.

\section{Sector-by-Sector Elasticity of Import Substitution}

\section{(1) Consumption Good Prices and Domestic Production}

Table 5.11 and Table 5.12 show the percent change in the price of consumption goods and total domestic production when the Armington elasticities of import substitution are differentiated sector by sector, rather than set uniformly for all sectors $\left(\rho_{m, j}=0.8 \forall j\right)$, as in the benchmark simulation. When we take sector-bysector elasticities given by Hummels (2001), the quantitative implications are not 
Table 5.11. Effect of Trade Liberalization on Consumption Good Prices $\left(\sigma_{m i} \neq \sigma_{m j}\right) \quad$ (unit:\%)

\begin{tabular}{|c|c|c|c|c|c|}
\hline \multicolumn{3}{|c|}{ (Ecuador) } & \multicolumn{3}{|c|}{ (Slovenia) } \\
\hline \multirow{2}{*}{ Sector } & \multicolumn{2}{|c|}{ Price Change } & \multirow{2}{*}{ Sector } & \multicolumn{2}{|c|}{ Price Change } \\
\hline & 'Hummels' & 'Rolleigh' & & 'Hummels' & 'Rolleigh' \\
\hline Bananas & 0.42 & 0.39 & Primary & 0.59 & 0.75 \\
\hline Cereals & -0.59 & -0.47 & Food \& Beverages & -1.03 & -1.85 \\
\hline Flowers & 0.55 & 0.61 & Textiles & -0.32 & 0.11 \\
\hline Petroleum & - & - & Leather & -1.31 & -0.74 \\
\hline Other Primaries & 0.29 & 0.33 & Wood Products & 0.27 & 0.48 \\
\hline Shrimp & 0.53 & 0.54 & Transport & -0.88 & -0.11 \\
\hline Textiles & -0.17 & -0.50 & Other Manufactures & 0.04 & 0.37 \\
\hline Chemicals & -0.26 & -0.23 & Services & 0.65 & 0.63 \\
\hline Transport & -1.53 & -1.69 & & & \\
\hline Other Manufactures & -0.41 & -0.34 & & & \\
\hline Services & 0.45 & 0.45 & & & \\
\hline
\end{tabular}

significantly different from the benchmark results as the averages of $\rho_{m}$ for the main import sectors are 0.825 for Ecuador and 0.814 for Slovenia. With the values used in Rolleigh (2003), however, the average elasticities are higher, 0.85 for main imports in Ecuador and 0.89 for Slovenia. At disaggregated levels, the higher the elasticities of substitution, the larger the impact on the price of consumption goods. Hence, with parameters estimated by Rolleigh (2003), the magnitude of price declines in Ecuador are 4.2 times for the textile sector and 25 percent larger for the transport sector than the benchmark results. In Slovenia, however, this is not always the case. In the food

Table 5.12. Effect of Trade Liberalization on Domestic Production $\left(\sigma_{m i} \neq \sigma_{m j}\right) \quad$ (unit:\%)

\begin{tabular}{|c|c|c|c|c|c|}
\hline \multicolumn{3}{|c|}{ (Ecuador) } & \multicolumn{3}{|c|}{ (Slovenia) } \\
\hline \multirow{2}{*}{ Sector } & \multicolumn{2}{|c|}{ Quantity Change } & \multirow{2}{*}{ Sector } & \multicolumn{2}{|c|}{ Quantity Change } \\
\hline & 'Hummels' & 'Rolleigh' & & 'Hummels' & 'Rolleigh' \\
\hline Bananas & 14.78 & 20.67 & Primary & 1.70 & -4.56 \\
\hline Cereals & -10.44 & -12.18 & Food \& Beverages & -3.42 & -38.75 \\
\hline Flowers & 4.11 & 11.00 & Textiles & 30.81 & 36.06 \\
\hline Petroleum & 1.49 & 4.12 & Leather & -10.62 & -9.55 \\
\hline Other Primaries & 0.80 & -0.53 & Wood Products & -3.78 & 0.49 \\
\hline Shrimp & 5.65 & 13.10 & Transport & 19.85 & 26.66 \\
\hline Textiles & -1.99 & -11.69 & Other Manufactures & 4.97 & 8.95 \\
\hline Chemicals & -2.98 & -2.43 & Services & -2.21 & -1.94 \\
\hline Transport & -8.08 & -15.53 & & & \\
\hline Other Manufactures & -1.89 & -6.10 & & & \\
\hline Services & -0.66 & -0.88 & & & \\
\hline
\end{tabular}


Table 5.13. Effect of Trade Liberalization on Main Exports $\left(\sigma_{m i} \neq \sigma_{m j}\right.$, 'Hummels') (unit:\%)

\begin{tabular}{lrrlrr}
\hline & (Ecuador) & \multicolumn{4}{c}{ (Slovenia) } \\
\hline \multicolumn{1}{c}{ Sector } & \multicolumn{1}{c}{ US } & \multicolumn{1}{c}{ ROW } & \multicolumn{1}{c}{ Sector } & EU & \multicolumn{1}{c}{ ROW } \\
\hline Bananas & 82.04 & -7.22 & Primary & 216.04 & -16.50 \\
Flowers & 12.60 & -8.90 & Food \& Beverages & 203.84 & 3.07 \\
Petroleum & 18.09 & -10.83 & Textiles & 108.99 & -5.86 \\
Other Primaries & 154.39 & -5.40 & Leather & 22.93 & 6.16 \\
Shrimp & 18.13 & -9.00 & Wood Products & -0.68 & -11.68 \\
& & & Transport & 67.73 & 0.69 \\
& & & Other Manufactures & 36.83 & -7.47 \\
\hline
\end{tabular}

Table 5.14. Effect of Trade Liberalization on Main Exports $\left(\sigma_{m i} \neq \sigma_{m j}\right.$, 'Rolleigh') ～(unit:\%)

\begin{tabular}{lrrlrr}
\hline & (Ecuador) & \multicolumn{4}{c}{ (Slovenia) } \\
\hline \multicolumn{1}{c}{ Sector } & \multicolumn{1}{c}{ US } & ROW & \multicolumn{1}{c}{ Sector } & EU & \multicolumn{1}{c}{ ROW } \\
\hline Bananas & $111.21 \%$ & $-8.20 \%$ & Primary & $264.33 \%$ & $-20.21 \%$ \\
Flowers & $28.86 \%$ & $-11.09 \%$ & Food \& Beverages & $300.21 \%$ & $12.55 \%$ \\
Petroleum & $34.53 \%$ & $-13.33 \%$ & Textiles & $132.69 \%$ & $-13.13 \%$ \\
Other Primaries & $191.71 \%$ & $-7.43 \%$ & Leather & $34.70 \%$ & $-3.58 \%$ \\
Shrimp & $35.99 \%$ & $-10.67 \%$ & Wood Products & $12.97 \%$ & $-16.73 \%$ \\
& & & Transport & $79.19 \%$ & $-10.85 \%$ \\
& & & Other Manufactures & $51.71 \%$ & $-14.97 \%$ \\
\hline
\end{tabular}

Table 5.15. Effect of Trade Liberalization on Main Imports ( $\sigma_{m i} \neq \sigma_{m j}$, 'Hummels') （unit:\%)

\begin{tabular}{|c|c|c|c|c|c|}
\hline \multicolumn{3}{|c|}{ (Ecuador) } & \multicolumn{3}{|c|}{ (Slovenia) } \\
\hline Sector & US & ROW & Sector & EU & ROW \\
\hline Cereals & 81.08 & -6.88 & Primary & 31.72 & -32.88 \\
\hline Other Primaries & 58.65 & 4.47 & Food \& Beverages & 64.71 & -11.35 \\
\hline Textiles & 148.76 & 1.97 & Textiles & 66.70 & -11.73 \\
\hline Chemicals & 33.61 & -0.41 & Leather & 37.24 & -1.64 \\
\hline Transport & 129.94 & -18.71 & Wood Products & 9.02 & -4.24 \\
\hline Other Manufactures & 38.46 & 0.02 & Transport & 44.07 & -14.67 \\
\hline & & & Other Manufactures & 25.65 & -10.89 \\
\hline
\end{tabular}

Table 5.16. Effect of Trade Liberalization on Main Imports $\left(\sigma_{m i} \neq \sigma_{m j}\right.$, 'Rolleigh') （unit:\%)

\begin{tabular}{lrrlrr}
\hline & \multicolumn{1}{c}{ (Ecuador) } & \multicolumn{4}{c}{ (Slovenia) } \\
\hline \multicolumn{1}{c}{ Sector } & \multicolumn{1}{c}{ US } & \multicolumn{1}{c}{ ROW } & \multicolumn{1}{c}{ Sector } & EU & \multicolumn{1}{c}{ ROW } \\
\hline Cereals & 53.78 & -8.48 & Primary & 18.03 & -40.29 \\
Other Primaries & 46.07 & 4.10 & Food \& Beverages & 294.20 & -57.44 \\
Textiles & 494.23 & -2.94 & Textiles & 86.76 & -33.77 \\
Chemicals & 17.88 & 0.35 & Leather & 36.84 & 9.47 \\
Transport & 193.26 & -30.59 & Wood Products & 21.88 & 3.25 \\
Other Manufactures & 66.97 & 0.27 & Transport & 46.98 & -14.82 \\
& & & Other Manufactures & 30.69 & -15.05 \\
\hline
\end{tabular}


and beverages sector, with a higher import elasticity, the price declines 75 percent more than under the benchmark elasticity, but in the transport sector, the magnitude of price decline is now smaller, despite higher a import elasticity. This may be due to the fact that in Slovenia, most sectors are both import and export intensive.

\section{(2) International Trade}

Tables 5.13 and 5.15 show the percent change in the volume of exports and imports for Ecuador and Slovenia using elasticities given by Hummels (2001), while Tables 5.14 and 5.16 show the corresponding trade volumes using elasticities given by Rolleigh (2003) On average, using the estimates taken from Rolleigh (2003), the exports and imports of Ecuador with the United States increase by $58.71 \%$ and $83.89 \%$, respectively. On the other hand, using the estimates taken from Hummels (2001), the corresponding numbers are $38.44 \%$ and $52.09 \%$, respectively. Compared to the benchmark simulation, the percent increase in trade is larger, especially when estimates are taken from Rolleigh (2003). Looking at the disaggregate level in the main import sectors, the import of transport equipments from the United States increases between 130-193\%, compared to $87 \%$ under the benchmark case. For the textiles sector, with the elasticity taken from Rolleigh (2003), the percent increase in the imports from the Unites States is around 494\%, which is a very large increase when compared to $112 \%$ under the benchmark case. Other main import sectors such as cereals and chemicals show smaller increase in imports from the United States. In contrast, the exports to and imports from the rest of the world decrease by 3 to $5 \%$, also showing larger magnitude compared to the benchmark

case.

For Slovenia, exports of all primary and manufactured goods to the European Union increase by 33 to $49 \%$, while imports from the European Union increase by 48 to $64 \%$. Regarding goods trade with the rest of the world, the exports decreased by 6 to $12 \%$, whereas the imports from the rest of the world fell by 13 to $21 \%$. Looking at individual sectors, the imports from non-EU countries in primary, food and beverages, and textiles sectors decrease significantly, by more than $30 \%$ when we take estimates from Rolleigh (2003). This fall is offset by a huge increase in the imports from the European Union in the corresponding sectors.

(3) Welfare

Finally, the impact of the full liberalization on national welfare is examined. For the government welfare of Ecuador, the tariff revenue falls by 33 to $36 \%$. This loss is partly reflected in the decline in the government welfare, which fell by around 4.6 to $5.7 \%$. However, the consumer's welfare gain partly offsets this government 
welfare loss. The overall social welfare gain in Ecuador is $0.03 \%$ under the estimates from Rolleigh (2003) and 0.20\% under Hummels (2001). For Slovenia, when we adopt estimates from Rolleigh (2003), the tariff revenue decreases by $11.48 \%$ due to larger decline in the imports from the rest of the world. On the other hand, tariff revenue increases by $2.75 \%$ under the estimates taken from Hummels (2001). However, both consumer and government welfare increase, and thus, the overall social welfare also shows an increase of $0.99 \%-1.57 \%$. The results are summarized in Table 5.17 .

\section{Fiscal Impact of Trade Liberalization: Ecuador}

For Ecuador, we observed that the tariff revenues decrease by a significant portion from signing a free trade agreement with the United States. For the benchmark case, the tariff revenue falls by more than $30 \%$. Even in the partial liberalization case, the revenue falls by $22 \%$. Finally, when we looked at differentiated sectoral import substitution elasticities, the magnitude was even higher at around $33 \%$ to $36 \%$. Because tariff revenues are an important source of government receipts in Ecuador, the loss in the government revenue accounts for the loss in the government's welfare when the country signs a free trade agreement. Our analysis in this section considers a different closure rule by requiring the Ecuadorian government to keep its deficit unchanged. Specifically, it assumes that the government imposes a new uniform indirect tax rate on the consumption goods (or the Value Added Tax) to keep its deficit unaltered. We find the increases required in the effective VAT rate for the benchmark simulation as well as the cases of partial liberalization and sectoral import substitution elasticities. As shown in Table 5.18 below, the required increase in the effective VAT rate ranges from 0.52 to 1.05 percentage points. As for the national welfare, despite the fall in the tariff revenue, the government welfare does not decline as much. Compared to $4.36 \%$ decline in the benchmark simulation, the decline in government welfare ranges from $0.46 \%$ to $0.69 \%$ when the government raises the indirect tax rate to keep its

Table 5.17. Effect of Trade Liberalization on Welfare $\left(\sigma_{m i} \neq \sigma_{m j}\right)$

(unit:\%)

\begin{tabular}{lcccc}
\hline \multirow{2}{*}{ Institution } & \multicolumn{2}{c}{ Ecuador } & \multicolumn{2}{c}{ Slovenia } \\
\cline { 2 - 5 } & 'Hummels' & 'Rolleigh' & 'Hummels' & 'Rolleigh' \\
\hline Consumer Welfare & 0.92 & 0.89 & 1.32 & 1.08 \\
Government Welfare & -4.60 & -5.73 & 2.68 & 0.64 \\
Social Welfare & 0.20 & 0.03 & 1.57 & 0.99 \\
\hline
\end{tabular}


Table 5.18. Fiscal Policy and Welfare - Ecuador

(Unit: Thousand US\$)

\begin{tabular}{lrrrrr}
\hline & $\begin{array}{c}\text { Data } \\
\text { SAM }\end{array}$ & $\begin{array}{c}\text { Benchmark } \\
\text { Simulation }\end{array}$ & $\begin{array}{c}\text { Partial } \\
\text { Liberalization }\end{array}$ & $\begin{array}{r}\text { 'Rolleigh' } \\
\text { elasticities }\end{array}$ & $\begin{array}{r}\text { 'Hummels' } \\
\text { elasticities }\end{array}$ \\
\hline $\begin{array}{l}\text { Tariff Reve- from US } \\
\text { nues } \quad \begin{array}{r}111,334 \\
\text { from ROW }\end{array}\end{array}$ & $\begin{array}{r}0 \\
278,529\end{array}$ & 267,468 & $\begin{array}{r}34,666 \\
270,273\end{array}$ & $\begin{array}{r}0 \\
249,949\end{array}$ & 261,291 \\
\hline $\begin{array}{l}\text { Effective VAT Rate } \\
\text { Compensatory Effective }\end{array}$ & $8.92 \%$ & & & & \\
VAT Rate & & $9.68 \%$ & $9.44 \%$ & $9.97 \%$ & $9.72 \%$ \\
\hline $\begin{array}{l}\text { Consumer Welfare } \\
\text { Government Welfare }\end{array}$ & & $0.39 \%$ & $0.22 \%$ & $0.20 \%$ & $0.39 \%$ \\
Social Welfare & $-0.65 \%$ & $-0.46 \%$ & $-0.69 \%$ & $-0.68 \%$ \\
\hline
\end{tabular}

deficit constant. However, the rise in the VAT rate negatively affects the consumer welfare, which only rises by $0.20 \%$ to $0.39 \%$, which is smaller than $0.90 \%$ increase shown under the benchmark simulation. The change in the overall social welfare gain ranges from $0.08 \%$ to $0.26 \%$.

\section{E. Free Trade Agreement vs. Customs Union: Slovenia}

In this section, we look at the hypothetical case of Slovenia signing a free trade agreement with the European Union, instead of joining the European Union as a full member. This requires that Slovenia and the European Union eliminate their tariffs on each other, while Slovenia retains its own tariff policy with the rest of the world, instead of adopting the tariff policy of the European Union. For comparison purposes, we take the case of uniform import elasticity used in the benchmark case and compare the result of two different liberalization policies. This comparison could provide a useful insight on the effects of different trade liberalization arrangements.

Table 5.19 shows the percent change in the price of consumption goods and total domestic production with different sectoral import substitution elasticities when Slovenia signs a free trade agreement with the European Union. One distinction in the free trade agreement experiment occurs in the primary sector, as the price declines under the free trade agreement, compared to an increase under the benchmark scenario. The largest decline in prices takes place in the leather, food and beverages, and transport sectors, by margins greater than $1 \%$. For food and beverages and transport sectors, the size of price decline is 18.8 percent and 9.4 percent greater than the benchmark results, respectively. Regarding domestic production, primary goods sector now records a decline in production of $3.47 \%$. 
Table 5.19. Effect of Free Trade Agreement on Price and Production - Slovenia （unit:\%)

\begin{tabular}{lcccc}
\hline & \multicolumn{2}{c}{ Consumption Good Price } & \multicolumn{2}{c}{ Domestic Production } \\
\cline { 2 - 5 } & Customs Union & FTA & Customs Union & FTA \\
\hline Primary & 0.54 & -0.20 & 1.12 & -3.47 \\
Food \& Beverages & -1.06 & -1.16 & -4.00 & -2.73 \\
Textiles & -0.30 & -0.64 & 31.41 & 32.63 \\
Leather & -1.25 & -1.11 & -2.59 & -2.06 \\
Wood Products & 0.26 & 0.33 & -5.14 & -4.15 \\
Transport & -0.90 & -1.07 & 21.83 & 22.54 \\
Other Manufactures & 0.03 & -0.02 & 5.06 & 5.88 \\
Services & 0.67 & 0.91 & -2.28 & -2.42 \\
\hline
\end{tabular}

For other sectors experiencing gains in production, the gains are larger under the free trade agreement than under the benchmark simulation.

Table 5.20 and 5.21 show the percent change in the volume of exports and imports to the European Union and the rest of the world, respectively. For total trade volume with the European Union, exports of all primary and manufactured

Table 5.20. Effect of Free Trade Agreement on Exports - Slovenia

(unit:\%)

\begin{tabular}{lcccr}
\hline & \multicolumn{2}{c}{ Exports to EU } & \multicolumn{2}{c}{ Exports to ROW } \\
\cline { 2 - 5 } & Customs Union & FTA & Customs Union & \multicolumn{1}{c}{ FTA } \\
\hline Primary & 214.00 & 247.86 & -15.13 & 6.67 \\
Food \& Beverages & 201.11 & 203.91 & 4.48 & 19.64 \\
Textiles & 105.60 & 114.50 & -5.26 & 12.14 \\
Leather & 20.25 & 17.54 & 6.22 & 17.81 \\
Wood Products & -1.81 & -2.49 & -10.69 & 0.64 \\
Transport & 65.92 & 68.68 & 1.89 & 17.52 \\
Other Manufactures & 35.24 & 37.64 & -6.45 & 8.02 \\
\hline
\end{tabular}

Table 5.21. Effect of Free Trade Agreement on Imports - Slovenia

(unit:\%)

\begin{tabular}{lcccc}
\hline & \multicolumn{2}{c}{ Imports from EU } & \multicolumn{2}{c}{ Imports from ROW } \\
\cline { 2 - 5 } & Customs Union & FTA & Customs Union & FTA \\
\hline Primary & 37.07 & 30.81 & -37.58 & -0.95 \\
Food \& Beverages & 69.26 & 71.53 & -12.67 & -2.84 \\
Textiles & 60.94 & 62.05 & -4.32 & 32.37 \\
Leather & 24.48 & 26.71 & 2.47 & -0.80 \\
Wood Products & 12.40 & 14.28 & -6.11 & -1.47 \\
Transport & 39.50 & 40.26 & -4.41 & 19.34 \\
Other Manufactures & 24.45 & 26.23 & -9.69 & 7.61 \\
\hline
\end{tabular}

goods increased by $49.59 \%$, while imports from the European Union increased by 
$32.95 \%$. Compared to the benchmark results, the figures are 7.3 percent higher for exports and 5.3 percent lower for imports. Regarding trade in goods with the rest of the world, the exports increased by $9.67 \%$, whereas the imports from the rest of the world also rose by $8.03 \%$ since free trade agreement does not cause trade diversion. Looking at individual sectors, primary imports from the rest of the world declines by around $1 \%$, compared to almost $38 \%$ decline under the benchmark simulation. In addition, some sectors exhibit large trade creation with both European Union and the rest of the world. For example, textiles imports from the rest of the world increases by $32.37 \%$, compared to $4.32 \%$ decline under the benchmark scenario, and this does not come at the cost of lower increase in imports from the European Union as the increase in textile imports from the European Union is still higher under the free trade agreement.

Finally, we examine the impact of signing a free trade agreement with the European Union on national welfare. Compared to the customs union case, the consumer welfare increases more under free trade agreement as Slovenia does not suffer from trade diversion while still gaining open access to the European Union market. The consumer welfare increase under the free trade agreement is approximately $28 \%$ larger than under the customs union benchmark case. However, the increase in government welfare is significantly smaller than under the customs union case, reflected in the government tariff revenue losses. The overall social welfare also shows an increase of $1.58 \%$, slightly less than the customs union scenario. The results are summarized in Table 5.22 .

\section{F. Exports Elasticity of Substitution and Welfare}

In this section, we conduct a sensitivity analysis regarding the relationship between the parameter that governs the exports elasticity of substitution $\left(\rho_{x}\right)$ and the national welfare for each country. Although we do not have calibrated values for $\rho_{x}$, we are interested in the optimal tariff argument presented initially in Johnson (1954), which states that for a small economy, as the $\rho_{x}$ parameter goes to

Table 5.22. Effect of Free Trade Agreement on Welfare - Slovenia

(unit:\%)

\begin{tabular}{lcc}
\hline & Customs Union & FTA \\
\hline Consumer Welfare & 1.37 & 1.76 \\
Government Welfare & 2.85 & 0.86 \\
Social Welfare & 1.66 & 1.58 \\
\hline
\end{tabular}


Table 5.23. Welfare (Full Liberalization Scenario) for Different $\rho_{x}$ - Ecuador $\quad$ (unit:\%)

\begin{tabular}{lrrrrrrrr}
\hline & 0.80 & \multicolumn{1}{c}{0.85} & \multicolumn{1}{c}{0.90} & \multicolumn{1}{c}{0.91} & \multicolumn{1}{c}{0.92} & \multicolumn{1}{c}{0.93} & \multicolumn{1}{c}{0.94} & \multicolumn{1}{c}{0.95} \\
\hline Consumer Welfare & 0.74 & 0.81 & 0.90 & 0.92 & 0.95 & 0.98 & 1.01 & 1.06 \\
Government Welfare & -4.50 & -4.48 & -4.36 & -4.31 & -4.23 & -4.13 & -3.98 & -3.76 \\
Social Welfare & 0.06 & 0.12 & 0.21 & 0.24 & 0.27 & 0.31 & 0.36 & 0.43 \\
\hline
\end{tabular}

Table 5.24. Welfare (Partial Liberalization Scenario) for Different $\rho_{x}$ - Ecuador $\quad$ (unit:\%)

\begin{tabular}{lrrrrrrrr}
\hline & \multicolumn{1}{c}{0.80} & \multicolumn{1}{c}{0.85} & \multicolumn{1}{c}{0.90} & \multicolumn{1}{c}{0.91} & \multicolumn{1}{c}{0.92} & \multicolumn{1}{c}{0.93} & \multicolumn{1}{c}{0.94} & \multicolumn{1}{c}{0.95} \\
\hline Consumer Welfare & 0.47 & 0.51 & 0.56 & 0.58 & 0.59 & 0.61 & 0.63 & 0.66 \\
Government Welfare & -3.16 & -3.12 & -3.01 & -2.97 & -2.91 & -2.84 & -2.73 & -2.58 \\
Social Welfare & 0.00 & 0.04 & 0.10 & 0.12 & 0.14 & 0.16 & 0.19 & 0.24 \\
\hline
\end{tabular}

1, the optimal tariff that the small economy should set goes to zero. We are interested on the validity of this claim for the trade liberalization episodes that are analyzed in this paper.

\section{(1) Ecuador:}

Table 5.23 and 5.24 show the percent change in welfare under different values of $\rho_{x}$ for the full liberalization versus the partial liberalization scenario, respectively.

From the comparison of the changes in social welfare, we note that for all values of $\rho_{x}$ tested, the social welfare gain is greater under the full liberalization scenario of free trade agreement than under the partial liberalization. The results are in line with the implications of optimal tariff discussed by Johnson (1954). Given the inverse relationship between the optimal tariff and the foreign export elasticity of substitution, we confirm that as the export elasticity of substitution increases, the optimal tariff becomes zero. Therefore, eliminating tariffs result in higher social welfare gains than lowering tariffs to a positive value. This seems to be of particular importance for Ecuador, as its main export goods are agricultural goods that are considered to have a high degree of substitutability.

\section{(2) Slovenia:}

Table 5.25 and 5.26 show the percent change in welfare under different values of $\rho_{x}$ for customs union and the free trade agreement scenario, respectively.

From the comparison of the changes in social welfare, we note that for values of $\rho_{x}$ greater than 0.93 , the social welfare gain is greater under the free trade agreement than under the customs union. The results are also in line with the implications of optimal tariff argument. Given the inverse relationship between the optimal tariff and the foreign export elasticity of substitution, we confirm that as the export elasticity of substitution increases, it becomes optimal for Slovenia to 
Table 5.25. Welfare (Customs Union Scenario) for Different $\rho_{x}$ - Slovenia (unit:\%)

\begin{tabular}{lcccccccc}
\hline & 0.80 & 0.85 & 0.90 & 0.91 & 0.92 & 0.93 & 0.94 & 0.95 \\
\hline Consumer Welfare & 0.98 & 1.13 & 1.37 & 1.43 & 1.51 & 1.60 & 1.72 & 1.89 \\
Government Welfare & 1.23 & 1.74 & 2.85 & 3.23 & 3.71 & 4.33 & 5.14 & 6.25 \\
Social Welfare & 1.03 & 1.25 & 1.66 & 1.79 & 1.95 & 2.15 & 2.41 & 2.76 \\
\hline
\end{tabular}

Table 5.26. Welfare (Free Trade Agreement Scenario) for Different $\rho_{x}$ - Slovenia (unit:\%)

\begin{tabular}{lrrrrrrrr}
\hline & \multicolumn{1}{c}{0.80} & \multicolumn{1}{c}{0.85} & \multicolumn{1}{c}{0.90} & 0.91 & 0.92 & 0.93 & 0.94 & \multicolumn{1}{c}{0.95} \\
\hline Consumer Welfare & 1.21 & 1.43 & 1.76 & 1.85 & 1.95 & 2.08 & 2.24 & 2.45 \\
Government Welfare & -0.96 & -0.36 & 0.86 & 1.28 & 1.79 & 2.44 & 3.28 & 4.40 \\
Social Welfare & 0.77 & 1.07 & 1.58 & 1.73 & 1.92 & 2.15 & 2.45 & 2.85 \\
\hline
\end{tabular}

sign a free trade agreement (and setting its tariffs to zero) rather than entering a customs union.

\section{Conclusions}

This paper analyzes the potential effects of two ongoing trade liberalization episodes: Ecuador signing a Free Trade Agreement with the United States and Slovenia joining the European Union as a full member. Using a calibrated applied general equilibrium model as our tool of analysis, we provide quantitative measures of the effects of these trade liberalization policies on production, prices, imports, exports, and welfare of the domestic consumers.

The predictions of the model are consistent with trade liberalization experiences observed in the past, with domestic production increasing in the export sectors and prices falling in the import sectors. Ecuadorian exports to the US and Slovenian exports to the EU show moderate increases in most sectors, while imports also show significant growth, especially in those sectors that were originally heavily protected. Since Slovenia adopts a more protectionist tariff schedule as it joins the EU, we observe that imports from the rest of the world fall significantly.

The impact on national welfare is mixed as Ecuador loses a large fraction of government tariff revenue, which drives down the aggregate social welfare despite gains in the consumers' welfare. For Slovenia, government tariff revenue increases due to the country's accession to the European Union and its adoption of a more protectionist tariff policy. Together with gains in the consumers' welfare, the overall social welfare increases.

It is important to note that this paper abstracts from several issues. First, due to 
the static nature of the model, this paper is not designed to capture the dynamic aspects of trade liberalization policies. Thus, some important issues of trade liberalization reforms, such as capital flows, foreign direct investment, and productivity gains and losses across sectors are beyond the scope of this paper. Adding dynamic features to the model would help shed light on these issues and capture the long term effects that these types of trade liberalization reforms encompass. These issues are of significant importance especially for the case of Ecuador (but also for Slovenia), which is a relatively capital poor economy opening not only to trade but to capital flows with its most important, and capital abundant, trade partner. Another interesting extension would be to quantify the impact of these trade liberalization reforms on different sectors of the society: for example, comparisons of the welfare effects of high-skilled households versus lowskilled ones, or comparisons about the welfare gains of urban households versus rural households. Incorporating these issues in a general equilibrium setting raises several challenging questions for future research.

\section{Acknowledgements}

We would like to thank Timothy J. Kehoe for his advice. We would also like to thank José María Da Rocha for his help at the early stages of this project, Gabriela Córdova at the Central Bank of Ecuador and Janja Kalin at the Statistical Office of the Republic of Slovenia for providing us crucial data sets for the quantitative section of this paper, and the participants at the Workshop on Modeling the Impact of the Expansion of the European Union (University of Minnesota, November 2004), the Midwest Economics Theory and International Trade Conference (Kansas University, October 2005), Workshop in Trade and Development (University of Minnesota, April 2006), and the Latin American and Caribbean Economic Associations Meeting (November 2006) for their suggestions and feedback. All remaining errors are ours.

Received 11 February 2008, Revised 2 April 2008, Accepted 7 April 2008 


\section{Appendix - Calibrated Parameters}

Table A1. Preference Parameters $(\theta)$ - Ecuador

\begin{tabular}{lcc}
\hline & Consumer & Government \\
\hline Bananas & 0.0033 & 0.0000 \\
Cereals & 0.0002 & 0.0000 \\
Flowers & 0.0013 & 0.0000 \\
Petroleum & 0.0000 & 0.0000 \\
Other Primaries & 0.0547 & 0.0000 \\
Shrimp & 0.0035 & 0.0000 \\
Textiles & 0.0627 & 0.0000 \\
Chemicals & 0.0474 & 0.0000 \\
Transport & 0.0144 & 0.0000 \\
Other Manufactures & 0.2761 & 0.0000 \\
Services & 0.3045 & 0.7617 \\
Investment Good & 0.2318 & 0.2383 \\
\hline
\end{tabular}

Table A2. Domestic Goods Firm Parameters $(\alpha, \beta)$ - Ecuador

\begin{tabular}{lcc}
\hline & $\alpha$ & $\beta$ \\
\hline Bananas & 0.1579 & 4.0015 \\
Cereals & 0.1754 & 4.3214 \\
Flowers & 0.7627 & 2.1949 \\
Petroleum & 0.8185 & 1.8043 \\
Other Primaries & 0.6241 & 4.7230 \\
Shrimp & 0.5566 & 3.2198 \\
Textiles & 0.4036 & 5.1114 \\
Chemicals & 0.4672 & 9.1552 \\
Transport & 0.3104 & 26.4270 \\
Other Manufactures & 0.6384 & 19.5090 \\
Services & 0.4238 & 3.2250 \\
\hline
\end{tabular}

Table A3. Armington Aggregators $(\gamma, \delta)$ - Ecuador

\begin{tabular}{lccccc}
\hline & $\gamma$ & $\delta_{\text {dom }}$ & $\delta_{U S}$ & $\delta_{A N D}$ & $\delta_{R O W}$ \\
\hline Bananas & 1.0000 & 1.0000 & 0.0000 & 0.0000 & 0.0000 \\
Cereals & 3.5131 & 0.3410 & 0.2584 & 0.1280 & 0.2726 \\
Flowers & 1.7852 & 0.7001 & 0.0799 & 0.0538 & 0.1662 \\
Petroleum & 1.0000 & 1.0000 & 0.0000 & 0.0000 & 0.0000 \\
Other Primaries & 2.8645 & 0.4271 & 0.1920 & 0.2003 & 0.1806 \\
Shrimp & 1.2565 & 0.8350 & 0.1096 & 0.0554 & 0.0000 \\
Textiles & 3.7137 & 0.3215 & 0.2046 & 0.2144 & 0.2595 \\
Chemicals & 3.9428 & 0.2764 & 0.2087 & 0.2277 & 0.2872 \\
Transport & 4.2467 & 0.2383 & 0.2469 & 0.2188 & 0.2960 \\
Other Manufactures & 3.7017 & 0.3257 & 0.2297 & 0.1896 & 0.2551 \\
Services & 2.8251 & 0.4315 & 0.1901 & 0.1847 & 0.1937 \\
\hline
\end{tabular}


Table A4. Preference Parameters $(\theta)$ - Slovenia

\begin{tabular}{lcc}
\hline & Consumer & Government \\
\hline Primary & 0.0364 & 0.0000 \\
Food \& Beverages & 0.1318 & 0.0000 \\
Textiles & 0.0377 & 0.0005 \\
Leather & 0.0121 & 0.0000 \\
Wood Products & 0.0005 & 0.0000 \\
Transport & 0.0460 & 0.0000 \\
Other Manufactures & 0.1397 & 0.0572 \\
Services & 0.2742 & 0.9287 \\
Investment Good & 0.3218 & 0.0136 \\
\hline
\end{tabular}

Table A5. Domestic Goods Firm Parameters $(\alpha, \beta)$ - Slovenia

\begin{tabular}{lcc}
\hline & $\alpha$ & $\beta$ \\
\hline Primary & 0.6875 & 4.0447 \\
Food \& Beverages & 0.3774 & 10.5440 \\
Textiles & 0.1589 & 6.3727 \\
Leather & 0.1911 & 4.7257 \\
Wood Products & 0.2546 & 5.5479 \\
Transport & 0.3364 & 16.1090 \\
Other Manufactures & 0.3586 & 6.4516 \\
Services & 0.3529 & 3.7414 \\
\hline
\end{tabular}

Table A6. Armington Aggregators $(\gamma, \delta)$ - Slovenia

\begin{tabular}{lcccc}
\hline & $\gamma$ & $\delta_{\text {dom }}$ & $\delta_{E U}$ & $\delta_{R O W}$ \\
\hline Primary & 2.8363 & 0.4147 & 0.3024 & 0.2830 \\
Food \& Beverages & 2.7753 & 0.4278 & 0.3107 & 0.2615 \\
Textiles & 2.8629 & 0.3873 & 0.3375 & 0.2752 \\
Leather & 2.9765 & 0.3551 & 0.3433 & 0.3016 \\
Wood Products & 2.5796 & 0.4672 & 0.3078 & 0.2250 \\
Transport & 2.8384 & 0.3759 & 0.3602 & 0.2638 \\
Other Manufactures & 2.8624 & 0.3879 & 0.3393 & 0.2728 \\
Services & 2.2782 & 0.5126 & 0.2515 & 0.2359 \\
\hline
\end{tabular}




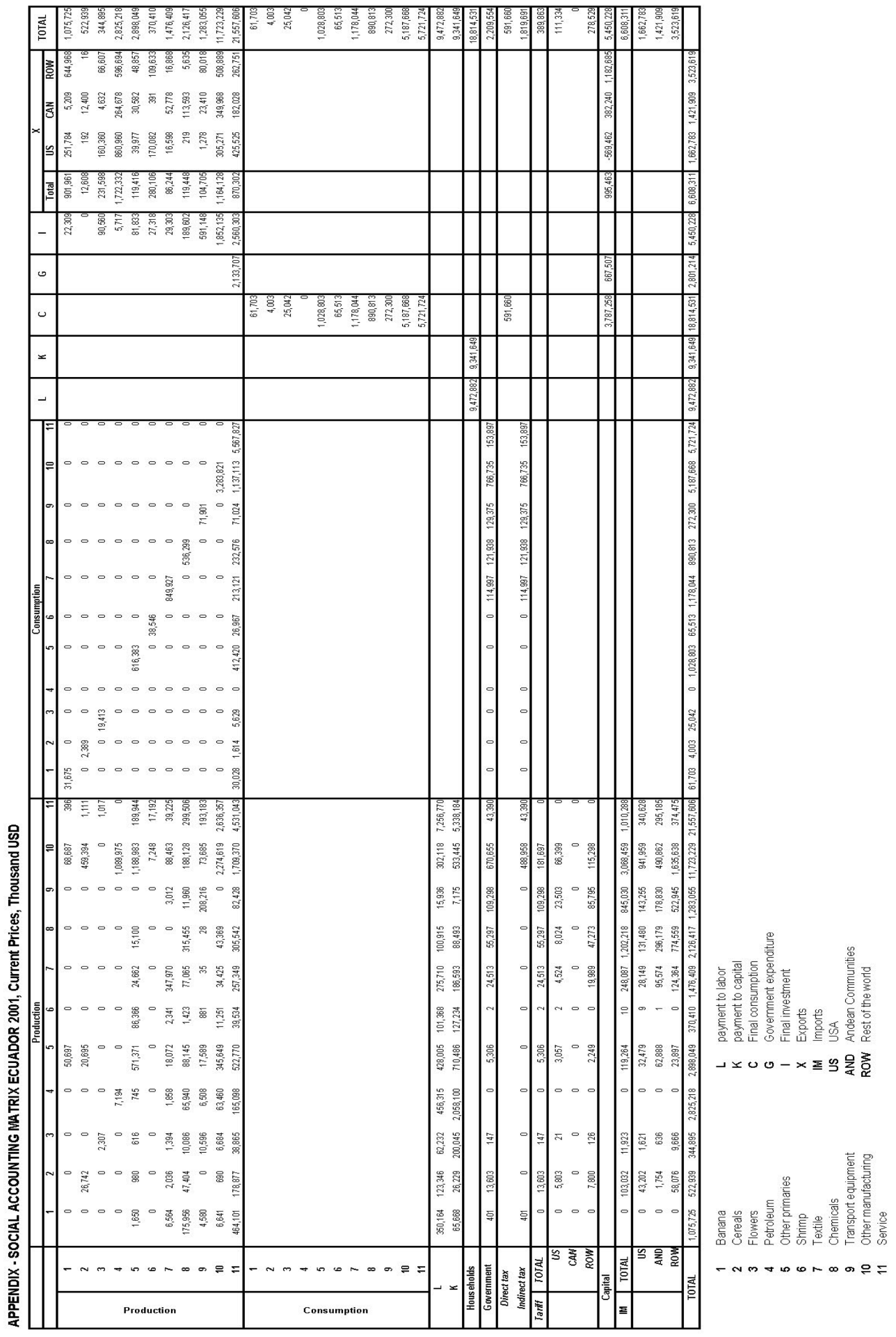




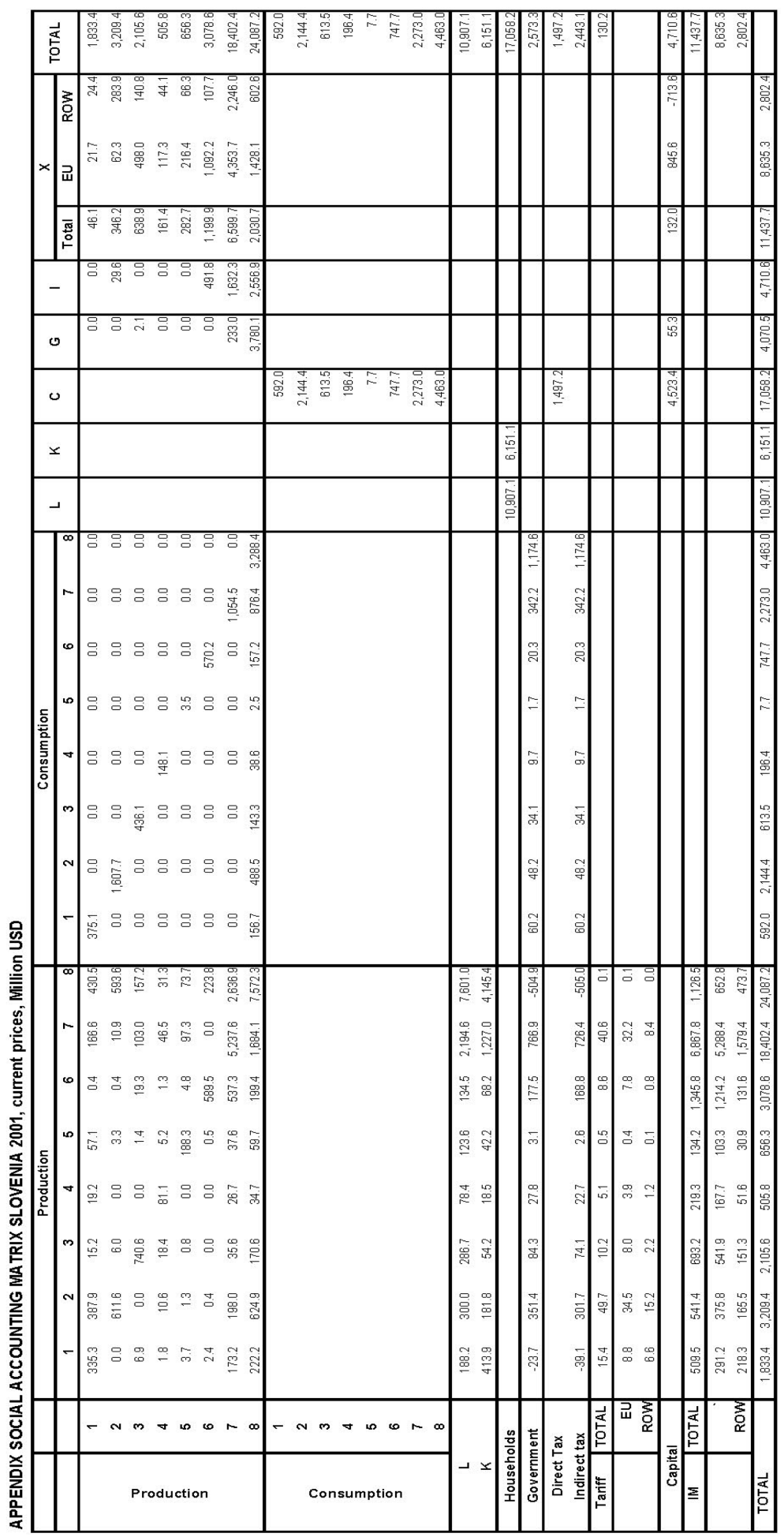

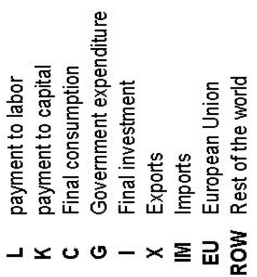

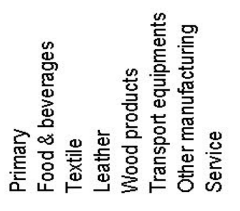




\section{References}

Banco Central del Ecuador (2004), Información Estadística Mensual. Quito, Ecuador.

Cho, S. and Díaz, J. (2008), "Welfare Impact of Trade Liberalization", Mimeo, University of New South Wales.

Hummels, D. (2001), “Toward a Geography of Trade Costs", GTAP Working Papers 1162, Center for Global Trade Analysis, Purdue University.

International Monetary Fund (2005), Direction of Trade Statistics, IMF, Washington, D.C. International Monetary Fund (2005), International Financial Statistics, IMF, Washington, D.C.

Johnson, H.G. (1954), “Optimal Tariffs and Retaliation”, Review of Economic Studies 21, 142-153.

Jorgenson, D. (1984), "Econometric Methods for Applied General Equilibrium Analysis", in Scarf, Herbert E. and Shoven, John B. (eds.) Applied General Equilibrium Analysis, New York, Cambridge University Press.

Kehoe, T.J. (1996), "Social Accounting Matrices and Applied General Equilibrium Models", Working Paper 563, Federal Reserve Bank of Minneapolis.

Kehoe, T.J. (2003), “An Evaluation of the Performance of Applied General Equilibrium Models of the Impact of NAFTA", Staff Report 320, Federal Reserve Bank of Minneapolis.

Kehoe, P.J. and Kehoe, Timothy J. (eds) (1995), Modelling North American Economic Integration, Boston: Kluwar Academic Publishers.

Pyatt, G. and Round, Jeffery J. (eds) (1985), Social Accounting Matrices - A Basis for Planning, World Bank, Washington, D.C.

Rolleigh, M. (2003), "Plant Heterogeneity and Applied General Equilibrium Models of Trade: Lessons from the Canada-US Free Trade Agreement", Mimeo, University of Minnesota.

Shoven, J.B. and Whalley, John (1984), “Applied General Equilibrium Models of Taxation and International Trade: an Introduction and Survey", Journal of Economic Literature, 22, 1007-51.

World Trade Organization (2005), Trade Policy Review: Ecuador, WTO, Geneva, Switzerland.

World Trade Organization (2002), Trade Policy Review: Slovenia, WTO, Geneva, Switzerland. 